\title{
A 100-Year Review: Practical female reproductive management ${ }^{1,2}$
}

\author{
J. S. Stevenson ${ }^{\star 3}$ and J. H. Britt $t^{4}$ \\ *Department of Animal Sciences and Industry, Kansas State University, Manhattan 66506-0201 \\ †Department of Animal Science, North Carolina State University, Raleigh 27695
}

\section{ABSTRACT}

Basic knowledge of mechanisms controlling reproductive processes in mammals was limited in the early 20 th century. Discoveries of physiologic processes and mechanisms made early in the last century laid the foundation to develop technologies and programs used today to manage and control reproduction in dairy cattle. Beyond advances made in understanding of gonadotropic support and control of ovarian and uterine functions in basic reproductive biology, advancements made in artificial insemination (AI) and genetics facilitated rapid genetic progress of economically important traits in dairy cattle. Technologies associated with management have each contributed to the evolution of reproductive management, including (1) hormones to induce estrus and ovulation to facilitate AI programs; (2) pregnancy diagnosis via ultrasonography or by measuring conceptus-derived pregnancy-associated glycoproteins; (3) estrus-detection aids first devised for monitoring only physical activity but that now also quantitate feeding, resting, and rumination times, and ear temperature; (4) sex-sorted semen; (5) computers and computerized record software packages; (6) handheld devices for tracking cow location and retrieving cow records; and (7) genomics for increasing genetic progress of reproductive and other economically important traits. Because of genetic progress in milk yield and component traits, the dairy population in the United States has been stable since the mid 1990s, with approximately 9 to 9.5 million cows. Therefore, many of these technologies and changes in management have been developed in the face of increasing herd size (4-fold since 1990), and changes from pastoral or dry-lot dairies to increased housing of cows in confinement buildings with freestalls and feed-line lockups. Management of groups of "like" cows

\footnotetext{
Received March 30, 2017.

Accepted May 10, 2017.

${ }^{1}$ This review is part of a special issue of the Journal of Dairy Science commissioned to celebrate 100 years of publishing (1917-2017).

${ }^{2}$ Contribution number 17-375-J from the Kansas Agricultural Experiment Station, Manhattan 66506.

${ }^{3}$ Corresponding author: jss@k-state.edu

${ }^{4}$ Current address: 212 Eagle Chase Lane, Etowah, NC 28729-8712.
}

has become equally important as management of the one. Management teams, including owner-managers, herdsmen, AI representatives, milkers, and numerous consultants dealing with health, feeding, and facilities, became essential to develop working protocols, monitor training and day-to-day chores, and evaluate current trends and revenues. Good management teams inspect and follow through with what is routinely expected of workers. As herd size will undoubtedly increase in the future, practical reproductive management must evolve to adapt to the new technologies that may find more herds being milked robotically and applying technologies not yet conceived or introduced.

Key words: dairy cow, management, reproduction, technology

\section{INTRODUCTION}

Management of reproduction in dairy cattle requires a mixture of science, technology, and the art of animal husbandry. Reproduction is a complex science, so much so that William Hansel, formerly of Cornell University, always told his students, "it is not a wonder that reproduction sometimes fails, but rather a miracle that so many pregnancies terminate successfully" (Bearden and Fuquay, 1997). It is also a wonder that so many pregnancies occur, given the innumerable ways in which the human can interfere in attempts to control the complex physiologic pathways and mechanisms that lead to and support pregnancy and eventual parturition.

Several factors during the last $100 \mathrm{yr}$ have influenced and altered how dairy cows are managed to promote reproductive efficiency. As the total number of dairy cows decreased with increased milk production per cow (Figure 1), herd size increased and nearly all dairy farms qualified as grade A milk producers, requiring upgrading of facilities and equipment. As a perspective from the 1920 US Census, 19.6 million dairy cows produced milk on 4.5 million dairy farms, representing an average of 4.4 cows per farm, and annual yield per cow was 1,385 L. In 2016, 9.3 million cows (223 cows per farm) produced milk on 41,809 dairy farms, and average production per cow was approximately 10,024 L (USDA, 2017). By 1950, average herd size was only 


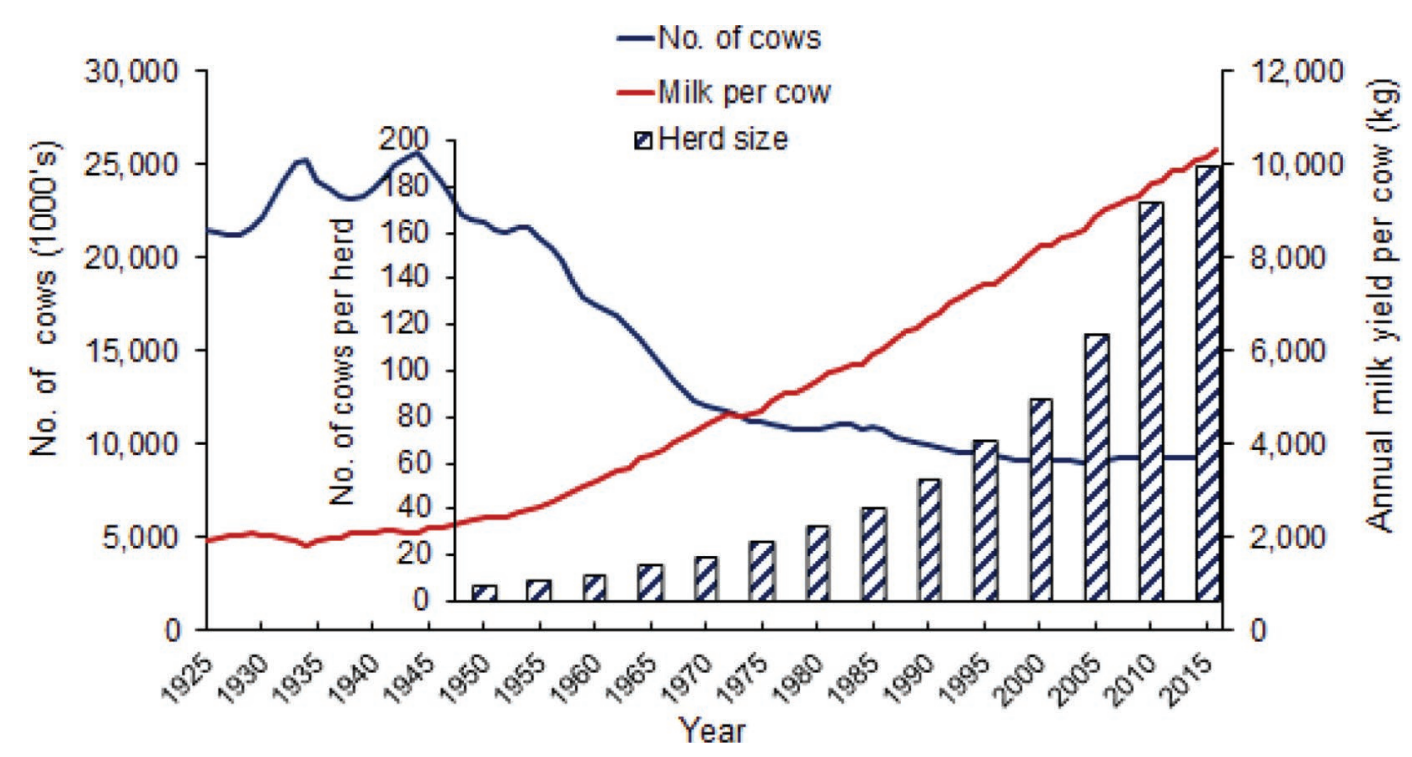

Figure 1. A historical summary of milk yield per cow, herd size, and numbers of dairy cows in the United States. Artificial insemination became commonplace in the 1950s with the advent of frozen semen and its adoption by dairy producers. Genetic progress in milk yield per cow is evident by the increasing yields after the 1960s when daughter-dam comparisons were replaced by a more sophisticated animal model that included genetic contributions of all female relatives of dairy sires in addition to their progeny. Source: NMPF (2016). Color version available online.

6.5 dairy cows per farm, but since then, it has increased exponentially (Figure 1). The numbers of herds with larger numbers of cows have also clearly changed. The number of cows per US dairy operation and its distribution by herd size reveals the exponential growth in large dairy herds beginning in the 1960s (Figure 2). Furthermore, proportion of total US milk produced annually by larger herds has increased dramatically since 1980. In $2012,63 \%$ of milk was produced by herds of 500 or more cows (NMPF, 2016). With 49,300 dairy herds in 2012, $63 \%$ of US milk was produced by only $35.7 \%$ of the dairy farms.

Average number of cows managed or volume of milk sold per dairy worker has increased with time and that is particularly true in larger than in smaller dairy herds (NDFS, 2015). Moreover, the labor force has changed culturally from predominantly immigrant Americanized Europeans to predominantly Hispanics, with the need for bilingual managers with a working knowledge of Spanish. Currently, Hispanic employees (of which approximately $63 \%$ are Mexican) represent approximately $75 \%$ of the hired labor force on dairy farms in California (Bello et al., 2012).

During the early half of the past century, most dairy cows grazed pastures and may have been housed in tiestall or stanchion barns during winter months. Housing types on US dairies then changed by growth of operations housed in freestall and dry-lot systems (NAHMS, 2007). The NAHMS (2007) survey was conducted in 17 of the United States' major dairy states, representing
$79.5 \%$ of US dairy operations and $82.5 \%$ of US dairy cows. Estimates in the NAHMS report refer to calendar year 2006. Further changes in the 1960s included greater usage of confinement housing, in which cows were housed almost exclusively on concrete after first calving. In these larger herds, adoption of feedline head lockups to confine cows individually after the morning milking introduced opportunities to manage much more efficiently reproduction and health care for large numbers of cows. Insemination, pregnancy diagnosis, health monitoring, and assessment of paint or tail chalk rubs as a means of detecting prior standing activity became much easier. Some managers without feedline lockups took advantage of return-alley sorting gates to segregate cows into palpation rails for various reasons or into a sorting pen with feedline lockups.

Key technologies and discoveries (Appendix Table A1) have led to changes in reproductive management and clearly have become important drivers for change in day-to-day management of dairy operations, particularly in larger herds. Breeding strategies have moved from predominantly natural service to an overwhelming prevalence of $\mathrm{AI}$ and ovulation-synchronization programs before timed AI (Caraviello et al., 2006). In the AI industry, changes in frozen semen packaging and sperm dose and use of sex-sorted semen facilitated genetic progress by making available more progeny of genetically proven sires (Foote, 1996). Detection of estrus by means of measuring correlated traits such as increased physical activity or body temperature became 


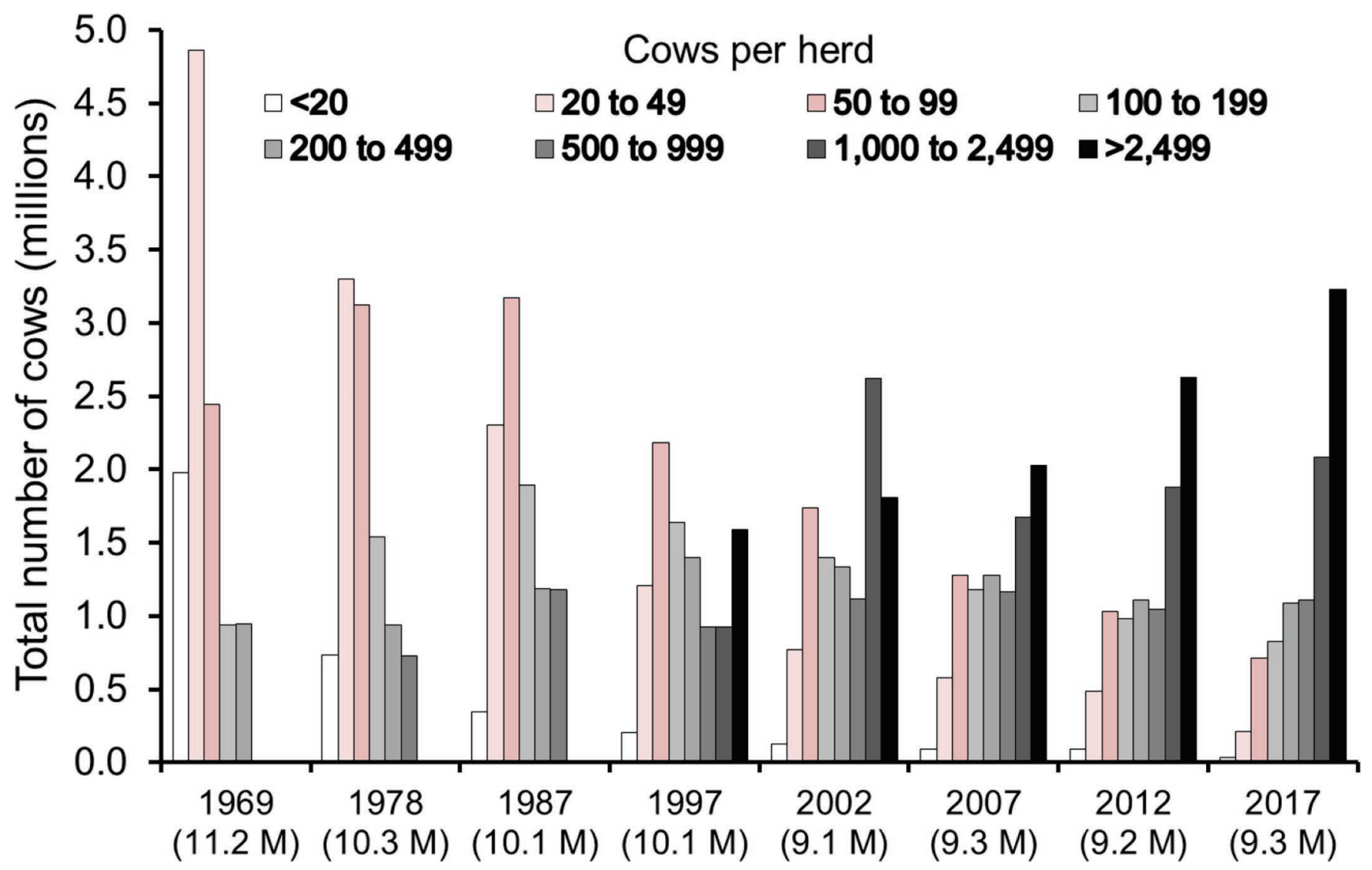

Figure 2. Change in the number (millions; M) of dairy cows per herd during the past 48 yr encompassing the period when freestall barns and larger parlors were built and much of the technology used today began to emerge. Data for 2017 represent a linear extrapolation from previous values. Source: USDA Census of Agriculture (http://agcensus.mannlib.cornell.edu/AgCensus/homepage.do; accessed March 24, 2017). Color version available online.

available in addition to single-use heat-mount detectors and permanent rump-mounted, pressure-sensitive electronic detectors that recorded mounts received by the cow in estrus (Roelofs et al., 2010). Pregnancy diagnosis occurred by means of transrectal palpation, transrectal ultrasonography, or by chemical tests as early as $28 \mathrm{~d}$ post-AI (NAHMS, 2007). Introduction of other assisted-reproductive techniques included embryo transfer, in vitro maturation of oocytes collected from ovaries of cows at slaughter, in vitro fertilization of those oocytes, followed by in vitro culture and transfer to recipient surrogate cows for gestation (RodriguezMartinez, 2012). Applying recombinant DNA-derived bovine somatotropin enhanced milk yields in addition to improved pregnancy rates of dairy cows in some studies.

The focus of this review will be to describe the history and impact of science and technology on reproductive management of dairy cattle during the 100-yr history of the Journal of Dairy Science. Readers are referred to previous reviews during the last $100 \mathrm{yr}$, which provide some insights to earlier assessments of technologies and reproductive management (Willett, 1956; Gomes and Erb, 1965; Foote, 1979, 1996, 2002; Britt et al., 1981; Moore and Thatcher, 2006).

\section{HISTORICAL DEVELOPMENTS IN REPRODUCTIVE MANAGEMENT}

At the dawn of the 20th century, there was limited knowledge of mechanisms that controlled reproduction in mammals. Discoveries made early in the century laid the foundation to develop technologies used today to manage and manipulate reproduction in dairy cattle. In this section, we briefly describe discoveries and advances that moved management of reproduction from breeding cows by natural service bulls of unknown genetic potential to more precise management that has emerged in the 21st century. A timeline illustrates the technologies and significant discoveries that were part of the past $100 \mathrm{yr}$ in reproduction and its management (Appendix Table A1). 


\section{Reproductive Records}

Williams (1919) recognized the need for common ways of comparing reproductive efficiency among herds. He proposed a simple approach by assigning $100 \%$ to each month that a heifer or cow remained in the herd with a calving interval of 12 mo or less, and $0 \%$ for each month beyond a 12-mo calving interval. His "Reproductive Months" comprised all months from when a heifer reached 15 mo of age until she was culled from the herd. Spielman and Jones (1939) subsequently utilized Williams' method to measure reproductive efficiency of different cow families and breeds from a 25-yr collection of records in the dairy herd at Oregon State Agricultural College. They reported different reproductive efficiencies among cow families ( 54.5 to $87.2 \%$ ) and among breeds (67.6 to $81.3 \%$ ). This scoring method represented the first attempt to measure reproductive performance using a single index.

Growth of AI associations in the United States beginning in the 1940s led to a systematic collection of reproductive data to compare fertility of bulls, AI technicians, and herds. Nonreturn rates $(60$ or $90 \mathrm{~d})$ were often used to estimate conception risk in lieu of actual pregnancy diagnosis. A related measure, services per conception, became a common variable for measuring herd fertility (Davis and Brost, 1953). None of these measures accounted for cows that were culled without being serviced, so they lacked a true assessment of the entire herd's reproductive performance.

Mead (1938) recognized this weakness and devised a method for tracking a herd's progress in time. His method used parallel hand-drawn lines on a large sheet of paper in which each cow's reproductive event (e.g., calving, estrus, pyometra, abortion, repeat service) was represented symbolically on one line. Each sheet could accommodate approximately 70 cows during a period of $5 \mathrm{yr}$ and established a systematic way of examining a herd's reproductive performance over time. This method was especially useful in visually depicting how a condition such as a Trichomoniasis infection affected herd performance.

Days open became a broadly used criterion in the 1960s because it included all cows eligible for breeding. Days open were also related to parity and economic returns from milk yield, leading Louca and Legates (1968) to recommend 13-mo calving intervals for primiparous cows and 12-mo calving intervals for multiparous cows. A reproductive index (Herd Reproductive Status; HRS) was developed in the 1960s and became part of some DHI record systems (Johnson et al., 1964). The HRS index included both average days open as well as the proportion of problem cows (those not pregnant $>100$ d).
These systems gradually lost their meaningfulness when synchronized breeding entered the picture - first with synchronized estrus and later with timed AI programs. Because almost all cows were inseminated by appointment on a weekly basis, a shift occurred to use voluntary waiting period (VWP) as the starting point for measuring reproductive performance at the herd level. By using VWP, managers had some leeway in deciding when to initiate first postpartum services without penalizing them for delaying first AI. A new status code "Do Not Breed" or DNB became vogue and allowed managers to identify cows that they planned to cull, thus excluding those cows from the breeding program and herd reproductive measures.

Traditional historical measures of reproductive efficiency such as days open, services per conception, and calving intervals have lesser value because they lack time sensitivity to current fertility trends in the herd. Risks for AI submission, estrus detection, and conception proved to have greater value but the combination of the latter in what is defined as the 21-d pregnancy rate has now become commonplace. By definition, a 21-d pregnancy rate is the proportion of breedingeligible cows in the herd becoming pregnant every $21 \mathrm{~d}$ beginning at the VWP. Its usefulness in assessing current insemination success was documented by Ferguson and Skidmore (2013) as a means to compare herds and monitor intra-herd progress in pregnancy risk.

The economic value of improving 21-d pregnancy rates has been estimated by various economic models (Cabrera, 2017). The annual per-cow value of improving the 21-d pregnancy rate from its current rate can be determined. For example, increasing a current 21-d pregnancy rate from 13 to $17 \%$ could result in a predicted annual increase in income of $\$ 97$ per cow per year. Increasing it from 18 to $24 \%$ results in a predicted increase of $\$ 100$ per cow per year. It is usually easier to increase 21-d pregnancy rates from lesser to greater rates $<20$ than endeavoring to increase $>25$. Furthermore, the increased economic returns increase at a decreasing rate when improvements are made above a 21 -d pregnancy rate of $25 \%$.

\section{Artificial Insemination}

Artificial insemination of cattle on a broad scale was pioneered by E. I. Ivanoff in the late 19th and early 20th centuries in Russia. By 1938, an estimated 1.2 million cattle in Russia had been inseminated under his programs (Perry et al., 1945). Danish leaders adopted Russian techniques and launched their first artificial breeding association in 1936, and by 1939, the Danes had established 21 associations across Denmark. In the United States, Cooperative Artificial Breeding Associa- 
tion No. 1 Inc. was launched in New Jersey in May 1938. By 1943, more than 14,000 cows had been inseminated in 1,600 herds served by 6 artificial breeding associations in New Jersey. In addition, approximately 100 breeding association cooperatives existed in the United States, with the greatest numbers in Wisconsin and New York (Perry et al., 1945).

Artificial insemination of cattle grew quickly and provided an incentive to understand more about time of ovulation in cattle and optimal timing for insemination. Brewster and Cole (1941) utilized repeated palpation of ovaries of heifers and cows during and after estrus to determine that ovulation occurred approximately 14 $\mathrm{h}$ after the end of estrus; however, duration of estrus was not measured accurately in that and many studies. Most believed that events at the end of estrus stimulated the follicle to ovulate. Nevertheless, these early estimates are within the range estimated by modernday ultrasonographic estimates of follicle disappearance (Dransfield et al., 1998).

At first, chilled fresh semen was stored in stoppered or screw-top vials that may have had sufficient sperm for servicing more than one cow. When frozen semen became available, it was packaged initially in glass ampoules and later in 0.25 - or $0.5-\mathrm{mL}$ plastic straws that could be more easily stored in liquid nitrogen containers specifically manufactured to store frozen semen on the farm. Today, different suppliers of bovine semen for AI use both sizes of straws for packaging their frozen semen. Meta-analyses applied to fixed- or randomeffect models of 15 different studies indicated that the average odds of having a greater pregnancy outcome were 3 to $4 \%$ greater with the $0.25-\mathrm{mL}$ straw than the 0.5-mL straw (Stevenson et al., 2009). Based on these odds ratios, the expected proportion of difference in pregnancy outcome translated into a difference of only $0.74 \%$.

As quality of semen extenders improved, studies focused on the optimal timing of insemination relative to onset of estrus and what types of daily service logistics were optimal for an AI technician to inseminate cows in a designated area. The question was whether technicians should visit farms in the morning and afternoon to inseminate cows detected in estrus at different times or whether once-daily visits were sufficient. Most AI organizations were using the a.m.-p.m. rule of thumb, in which cows first detected in estrus in the a.m. were inseminated later in the p.m. and those in first detected in the p.m. were inseminated the next a.m. (Trimberger and Davis, 1943). Inseminating cows during the a.m. and p.m. limited the number of herds that could be serviced by one AI technician. Field trials with chilled, extended semen (Foote, 1979) and frozen semen (Nebel et al., 1994) demonstrated that once-a-day service was optimal and that any cow detected in estrus after a previous daily visit should be inseminated when the technician arrived at the farm the next day. The number of doses of bovine semen produced worldwide during the last $50 \mathrm{yr}$ exceeds 250 million (RodriguezMartinez, 2012).

The increase in milk yield per cow in the United States during the last century has been driven by genetic selection for milk yield and milk components (Figure 1). The first national sire evaluations were calculated in 1936. The USDA's Animal Improvement Programs Laboratory (Beltsville, MD) was originally tasked to conduct research, discover, test, and implement improved genetic evaluation techniques for economically important traits of dairy cattle. Data were collected and research was directed at genetic improvement of yield traits (e.g., milk, fat, lactose, and protein) and non-milk yield traits that affect health and profitability (longevity, udder conformation, fertility, and disease resistance) of dairy cows. Today, the Council on Dairy Cattle Breeding (Bowie, MD) utilizes records from herds participating in DHIA that are processed at 4 national processing centers (AgriTech Analytics, Visalia, CA; AgSource Cooperative Services/CRI, Verona, WI; DHI Computing Service Inc., Provo UT; and Dairy Records Management Systems, Raleigh, NC). These records provide information on progeny daughters of bulls from which sire summaries are calculated and published regularly.

Despite advantages of using AI, not all cows and heifers are bred by AI. A survey conducted in 103 Alta Genetics (Watertown, WI) progeny-test herds (averaging 613 cows) located in 18 states (Caraviello et al., 2006) found that $56 \%$ of the herds used AI for all breeding services. In addition, a national survey sponsored by the National Association of Animal Breeders (NAAB; Madison, WI) revealed that, depending on herd size, 55 to $63 \%$ of dairy heifers were serviced using AI. A more recent NAAB survey showed that 62 to $68 \%$ of dairy heifers received at least 1 AI service (Fricke, 2004). As recently as 2007 , more than $72.5 \%$ of pregnancies achieved in dairy operations resulted from AI, whereas $26.8 \%$ occurred after natural mating, with relatively little variation among herds of different size (Table 1; NAHMS, 2007).

Today, about half of all dairy operations (51.5\%) have bulls used for breeding dairy cows (NAHMS, 2014). The NAHMS (2014) study was conducted in 17 of the United States' major dairy states, representing $76.7 \%$ of US dairy operations and $80.3 \%$ of US dairy cows at the time of the study interview. Estimates provided here refer to calendar year 2013. Beef bulls were used for breeding dairy cattle on $5.5 \%$ of dairy operations, whereas dairy bulls were used on $48.1 \%$ of 
operations. A smaller percentage of small operations (30 to 99 cows; $48.2 \%$ ) used bulls compared with large operations ( $>500$ cows; $62.8 \%$ ). Natural service was the second most common practice used at first service for most heifers and cows (33.2 and $21.7 \%$ of operations, respectively).

Sex-sorted semen has been available in the US market since 2003. Altering the sex ratio in favor of heifer calves has led to a greater abundance of replacement heifers in dairy operations, facilitating, if desired, internal growth of the herd. Sorting sperm based on their DNA content was successfully done in 1987 by flow cytometry, allowing relatively pure populations of $\mathrm{X}$ - and Y-chromosome-bearing sperm to be collected (Moore and Thatcher, 2006). Disadvantages of applying sex-sorted semen are its cost and reduced fertility. The early technology for sorting sperm was relatively slow (150 to 200 straws of sexed semen per machine per day), and commercial straws have smaller doses (e.g., 2 million sperm per straw) compared with conventional semen, which is packaged in doses of 10 million or more sperm per straw. A big improvement during the past $10 \mathrm{yr}$ has increased speed and efficiency of each sorting unit, resulting in a doubling of output. Packaging 2 million sperm per AI dose under ideal conditions now produces approximately 14 straws of sex-sorted semen of each sex per hour or 672 straws per day (Seidel, 2014).

Pregnancy outcomes with sex-sorted sperm are generally 70 to $85 \%$ of what can be achieved with conventional semen in well-managed herds (DeJarnette et al., 2009). Because of the cost of producing sex-sorted semen and poorer fertility associated with its application, most of it is used in heifers because they are the most fertile females on a dairy operation. For dairy operations with pregnancies produced by AI during 2006, sex-sorted semen was used to inseminate $11.4 \%$ of heifers and $3.5 \%$ of cows (NAHMS, 2007).

\section{Discovery and Assay of Reproductive Hormones}

Pituitary and gonadal reproductive hormones were discovered in the third and fourth decades of the 20th century. Estrogens were isolated and characterized from ovarian follicular fluid (Allen and Doisy, 1923), progesterone from corpora lutea (Allen, 1930), and LH and FSH from pituitary glands (Fevold et al., 1931).

Bioassays were used to estimate relative amounts of hormones in urine and tissues during the first 7 decades of the 20th century. The earliest bioassays estimated estrogenic hormones in urine of cattle during pregnancy (Hisaw and Meyer, 1929; Nibler and Turner, 1929). For example, Nibler and Turner (1929) stimulated cows to urinate at planned times throughout gestation and
Table 1. Average percentage of pregnancies conceived during 2006 according to breeding method and size of US dairy operation (NAHMS, 2007)

\begin{tabular}{|c|c|c|c|}
\hline \multirow[b]{2}{*}{ Herd size } & \multicolumn{3}{|c|}{ Breeding method (\%) } \\
\hline & Natural service $^{1}$ & $\mathrm{AI}^{2}$ & Embryo transfer ${ }^{3}$ \\
\hline$<100$ cows & 29.1 & 70.3 & 0.6 \\
\hline 100 to 499 cows & 22.0 & 77.0 & 1.0 \\
\hline$\geq 500$ cows & 19.7 & 79.9 & 0.4 \\
\hline Âll herds & 26.8 & 72.5 & 0.7 \\
\hline
\end{tabular}

${ }^{1}$ Bull bred.

${ }^{2}$ After detected estrus or timed AI.

${ }^{3}$ Superovulated or in vitro-derived embryos.

then extracted estrogenic activity by mixing olive oil with the urine. The oil was then separated from the aqueous fraction and used in a rat uterine bioassay. Estrogenic activity estimated by rat units (relative increase in weight of the uterus) increased 19-fold from the beginning to the end of gestation in cows.

Casida (1938) provided an insightful overview of actions of crudely purified gonadotropic hormones in laboratory animals and cattle. Bioassays of gonadotropins often used responses observed in immature female rats or male chicks. For example, Nalbandov and Casida (1940) removed pituitaries from cattle at different stages of pregnancy, minced pituitary pieces in acetone, dried the material, and created a powder with mortar and pestle. Approximately $25 \mathrm{mg}$ of powder was loaded into gelatin capsules and then inserted (i.m. or s.c.) into rats at approximately $31 \mathrm{~d}$ of age. Ovaries of rats were removed 4 to $5 \mathrm{~d}$ later and weighed. Heavier weights reflected greater gonadotropic activity. For male chicks, dried powder was injected as an aqueous solution daily for $7 \mathrm{~d}$ beginning at $14 \mathrm{~d}$ of age, and testes were removed and weighed when chicks were $21 \mathrm{~d}$ of age.

Hormone assays were not very sensitive until the late 1960 s, often requiring several milliliters or liters of urine or blood to assess a single sample. Various types of chromatography were used subsequently to separate active hormonal agents, which were then measured using spectrophotometric procedures (Gomes and Erb, 1965). In the late 1960s and early 1970s, protein binding assays and radioimmunoassays were developed and these increased sensitivity up to a thousand-fold (Midgley et al., 1969; Niswender et al., 1969). Immunoassays were sufficiently sensitive, requiring assay of only microliters of biological fluid (e.g., tissue extracts, blood, or milk). Increased assay sensitivity facilitated frequent and multiple sampling of animals to detect secretory patterns over minutes, hours, or days. It became possible to detect pulsatile secretion of hormones surrounding key reproductive events such as parturition, estrus, ovulation, or luteolysis. 


\section{Eradication of Brucellosis}

No historical report summarizing reproductive management of dairy cattle would be complete without mentioning efforts made to eradicate brucellosis (Ragan, 2002). Brucellosis (Bang's disease) caused by Brucella abortus was by far the most significant reproductive disease of cattle in the United States during the first half of the previous century. It affected dairy herds by increasing abortions and reducing fertility. Furthermore, it was a threat to human health through transmission to humans who consumed unpasteurized milk. Steps were underway in some states in the 1930s to eradicate the disease, but the problem was nationwide. The US Congress appropriated funds in 1954 to launch a national eradication program. Testing spread to all states by 1957 and 124,000 infected herds were soon identified. Testing revealed from one-third to onehalf of herds were infected based on data from cattle slaughtered for meat production.

One of the authors (JHB) recalls veterinary visits to his family's dairy farm when all cows were blood tested and cows that were "positive" were branded on the jaw with a "B" and those that had a "suspect" test were branded with an "S." If a cow received such a brand, its owner was entitled to an indemnity and branded cows had to be slaughtered. It took almost half a century to eradicate brucellosis in cattle herds, and small pockets of the disease remained in bison and deer in various regions of the United States. Brucellosis is still prevalent at modest to high rates in countries around the world.

\section{Control of Estrous Cycles}

Progesterone and Progestins. Progesterone was first used to manipulate estrous cycles of cattle during the late 1940s and early 1950s (Ulberg et al., 1951). These early studies showed that progesterone $(50 \mathrm{mg})$ administered daily in a vegetable oil base was effective in preventing estrus and ovulation. Estrus typically occurred 4 to $5 \mathrm{~d}$ after progesterone withdrawal, but fertility at that estrus was compromised (Trimberger and Hansel, 1955). To avoid having to administer daily injections, Nellor and Cole (1956) used microcrystalline progesterone suspended in a starch solution administered in a single injection to synchronize estrus. Their approach was successful but the precision of synchronization was poorer than that observed following daily injections.

Orally active progestins were first fed to cattle to synchronize estrus in the 1960s (Patterson et al., 1989). For example, field trials evaluated effectiveness of 2 progestins [6-chloro- $\Delta^{6}$-dehydro-17-acetoxyprogesterone (CAP) and 6-methyl-17-acetoxyprogesterone (MAP)] provided in liquid or pelleted forms to control time of estrus in cows (Hansel, 1961). Progestins were typically fed for 14 to $18 \mathrm{~d}$ and cows exhibited estrus 4 to 6 d after withdrawal of the progestin from feed (Boyd, 1970). Synthetic progestins such as $17 \alpha$-acetoxy-9 $\alpha-$ fluoro-11 $\beta$-hydroxyprogesterone (cronolone) also were incorporated into vaginal sponges for use in cattle (Carrick and Shelton, 1967).

Although progestins were reasonably effective in synchronizing time of estrus, fertility was consistently less than that observed in contemporary controls. Furthermore, concerns were expressed about synthetic progestins appearing in milk of dairy cows. One synthetic progestin, melengestrol acetate (MGA), was found to be very effective in preventing expression of estrus in feedlot heifers while also improving weight gain and feed efficiency (Lauderdale, 2009). This product continues to be used for this purpose and is used in combination with prostaglandin $\mathrm{F}_{2 \alpha}\left(\mathrm{PGF}_{2 \alpha}\right)$ to synchronize estrus in dairy heifers and beef cattle.

Grouping Cows for Reproductive Management. Once progestin products for synchronizing estrus became available, the concept of grouping or clustering cows (i.e., weekly or biweekly) according to calving dates for group management was introduced (Britt et al., 1972; Folman et al., 1984). The scheme utilized in the former report for dairy cows (Figure 3) used MGA to synchronize first inseminations and the next potential insemination, whereas in the latter report a progesterone-impregnated intravaginal insert and $\mathrm{PGF}_{2 \alpha}$ analog were used. These grouping schemes are prototypes for what is done today to cluster cows for timed AI.

\section{Intervention Technologies}

In the late 1960s, discovery of hypothalamic peptides that control secretory function of the anterior pituitary

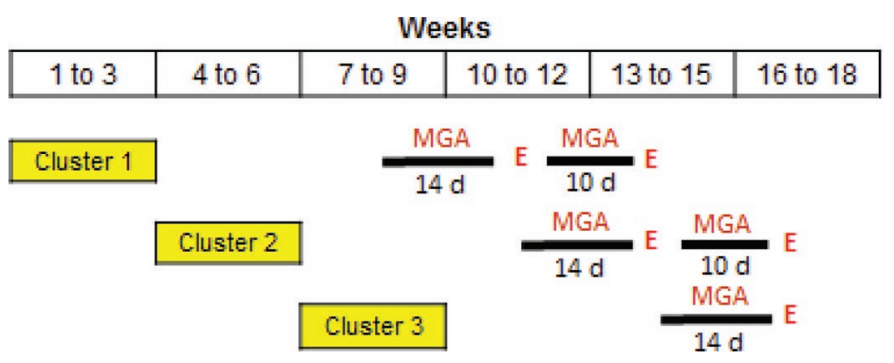

Figure 3. Proposed clustering of dairy cows after calving to facilitate synchronization of estrous cycles by feeding melengestrol acetate (MGA: $0.5 \mathrm{mg} /$ cow per day) first for $14 \mathrm{~d}$ and thereafter for $10 \mathrm{~d}$ to cows not inseminated initially at estrus (E) after the first 14-d feeding (Britt et al., 1972). Clustering accommodated synchrony of all breedings to just a few days per week. Color version available online. 
led to sequencing and synthesis of gonadotropin-releasing hormone $(\mathrm{GnRH})$. At about the same time, highly sensitive and precise radioimmunoassays were developed to detect nanomolar concentrations of biological substances in blood and tissue. These discoveries led to a shared Nobel Prize in Physiology or Medicine by Roger Guillemin, Andrew Schally, and Rosalyn Sussman Yalow in 1977 (Yalow, 1978).

Several newly discovered hormones and delivery technologies were introduced for control of estrous cycles and ovulation in domestic animals in the early 1970s. Many early reports of these technologies were presented at a 1974 conference on Control of Sexual Cycles in Domestic Animals (Anon, 1975). Among technologies that were highlighted at this conference were applications of (1) $\mathrm{PGF}_{2 \alpha}$ and its analogs as luteolytic agents; (2) $\mathrm{GnRH}$ and its analogs to induce ovulation; (3) intravaginal progesterone-impregnated silicone spirals for administering progesterone to synchronize estrus; and (4) timed AI to inseminate cows after synchronized estrus or ovulation.

$\boldsymbol{P} \boldsymbol{F}_{2 \alpha}$. The finding that $\mathrm{PGF}_{2 \alpha}$ could decrease progesterone in ovaries of pseudo pregnant rats and terminate pseudo pregnancy led to its discovery as a luteolytic hormone (Pharriss and Wyngarden, 1969). Several preliminary reports in 1972, and later reviewed by Lauderdale (2009), documented luteolytic actions of $\mathrm{PGF}_{2 \alpha}$ in cattle. Potent analogs were developed subsequently and use of luteolytic prostaglandins expanded to application in multiple species.

$\boldsymbol{G n R H}$. Discovery of the amino acid sequence of LHreleasing hormone soon led to its synthesis (Amoss et al., 1971; Matsuo et al., 1971a,b). Thereafter, several reports documented the effectiveness of $\mathrm{GnRH}$ for inducing secretion of LH in heifers (Zolman et al., 1973), normal cows, and cows with ovarian follicular cysts (Kittok et al., 1973), and for inducing LH release and ovulation in lactating dairy cows (Britt et al., 1974). Studies demonstrated that injection of GnRH induced release of LH and FSH (Britt et al., 1981), and later that it was effective for inducing ovulation of bovine ovarian follicles $\geq 10 \mathrm{~mm}$ in diameter during approximately $64 \%$ of the estrous cycle (Moore and Thatcher, 2006).

Progesterone Inserts. A progesterone-impregnated silicone-coated flat stainless steel insert, twisted into a coil so that it could be easily inserted into the vagina, later marketed as the progesterone-releasing intravaginal device (PRID), released progesterone at concentrations sufficient to suppress estrus for more than 3 wk. When tested in cows, the PRID successfully synchronized estrus (Mauer et al., 1975; Roche, 1975). Another intravaginally placed progesterone-impregnat- ed insert known as the controlled internal drug release or CIDR insert was introduced in the 1990s in New Zealand (Macmillan and Peterson, 1993) and is now used worldwide in combination with $\mathrm{PGF}_{2 \alpha}$, GnRH, or both.

Timed AI. With hormonal products available to synchronize estrus or ovulation, scientists sought to inseminate cows at preplanned times without regard to detection of estrus. The first 2 reports of success with timed AI applied similar approaches. In the first, Mauer et al. (1975) inserted PRIDs into 396 nonlactating cows and heifers for $21 \mathrm{~d}$, injected GnRH 28 to $30 \mathrm{~h}$ after PRID removal, and inseminated cows with frozen-thawed semen 18 to $24 \mathrm{~h}$ after GnRH. Conception risk did not differ between cows inseminated by appointment and those inseminated based on detected estrus. Roche (1975) shortened the duration of PRID treatment in 367 Friesian dairy cows to $12 \mathrm{~d}$, injected $5 \mathrm{mg}$ of estradiol benzoate and $50 \mathrm{mg}$ of progesterone at the time of PRID insertion, and injected GnRH 30 $\mathrm{h}$ after PRID removal. Cows were inseminated $48 \mathrm{~h}$ after PRID removal or $18 \mathrm{~h}$ after GnRH. Fertility was reported to be normal.

\section{CURRENT TECHNOLOGIES AND MANAGEMENT}

\section{Estrus-Detection Systems}

Detecting Estrus. Artificial insemination is the most viable option to produce pregnancies in dairy cows; however, implementation of a successful AI program on dairy farms requires accurate and efficient detection of estrus, even if timed AI is used for first or later services. Several significant physiological changes have been reported to occur during the periestrual period (Lewis and Newman, 1984; Roelofs et al., 2010) that enable detection of estrual behavior and other correlated traits in cows. Some of these changes include physical activity; vaginal cytology and $\mathrm{pH}$; electrical resistance of vaginal mucus and genital tissues; body temperatures; pulse and heart rates; blood flow; rumination time; pheromones, blood metabolites, and hormones; milk yield; and feed intake.

Cows are monitored traditionally for visual signs of estrus such as "standing to be mounted" by a herdmate. To be effective in identifying when to inseminate, visual observation of cows should occur for at least $30 \mathrm{~min}$ twice daily in the morning and late afternoon or early evening. Challenges associated with visual detection of estrus were increased by changes in housing and footing surfaces that occurred in the early 1970s. Approximately $76 \%$ of large dairy herds (>500 cows) in the United States house dairy cows in confinement freestall 
barns with concrete flooring. An estimated $32 \%$ of those freestall operations also have turnout dry lots. Only $17 \%$ of all large operations have cows only in dry lots (NAHMS, 2014). One of the most important factors limiting expression of sexual behavior in lactating Holstein cows is the surface on which they are observed for estrus. Cows are likely to express estrous behavior more often and for longer durations when detected for estrus on earthen surfaces rather than on dry grooved concrete surfaces (Britt et al., 1986).

Estrus-Detection Aids. To reduce labor and improve efficiencies associated with detection of estrus, procedures and methods were developed to detect estrus in absence of visual observations. The state of the art for early estrus-detection aids was reviewed thoroughly by Foote (1975). Described were pressuresensitive devices affixed to the tail head of cattle that were triggered (color indicators) when a cow stood to be mounted and a marking harness worn by a sexually aggressive or testosterone-treated cow or heifer (Kiser et al., 1977) that applied a colored ink stripe to the back of estrual females when mounted by the marking animal. The newest version of tail-head-applied patches is made like a lottery or scratch-off ticket that reveals a new color once the outer gray film of the patch is rubbed off by the mounting female.

Mounting pressure-sensitive sensors to the rump of the cow that are activated by a mounting herdmate were developed in the mid 1990s (Stevenson et al.,
1996). The accuracy and efficiency of these systems are quite high because they are associated with specific sexual behavior and are functional $24 \mathrm{~h} / \mathrm{d}$ (Roelofs et al., 2010). The downside to these systems is the labor associated with applying the sensor patches and the maintenance to keep sensor patches affixed to cows until pregnancy occurs.

Today, technologically simple products such as paint or chalk applied to the tail head remain the most common forms of estrus-detection aids in US dairy operations, second only to visual observation (Figure 4 ). When painted or chalked cows are mounted from the rear, some of the chalk or paint is rubbed off, indicating that the rubbed cow possibly stood in estrus when mounted by a herdmate. Validation of accurate rub marks by concentrations of progesterone in milk or subsequent pregnancy after insemination showed that accuracy of chalk- or paint-rub marks as estrus-detection methods varied widely from 33 to $90 \%$ (Stevenson and Phatak, 1999). It seems from many studies that 5 to $30 \%$ of cows or heifers inseminated are not really in estrus (Roelofs et al., 2010).

Automated Estrus Detection. Automation of estrus detection by novel systems in dairy cows is well documented (Firk et al., 2002). Before 2006, automated estrus-detection aids were limited to pressure-sensitive rump-mounted devices and pedometers (Figure 4; NAHMS, 2007). Technologies developed to take advantage of physiological correlates of estrus include

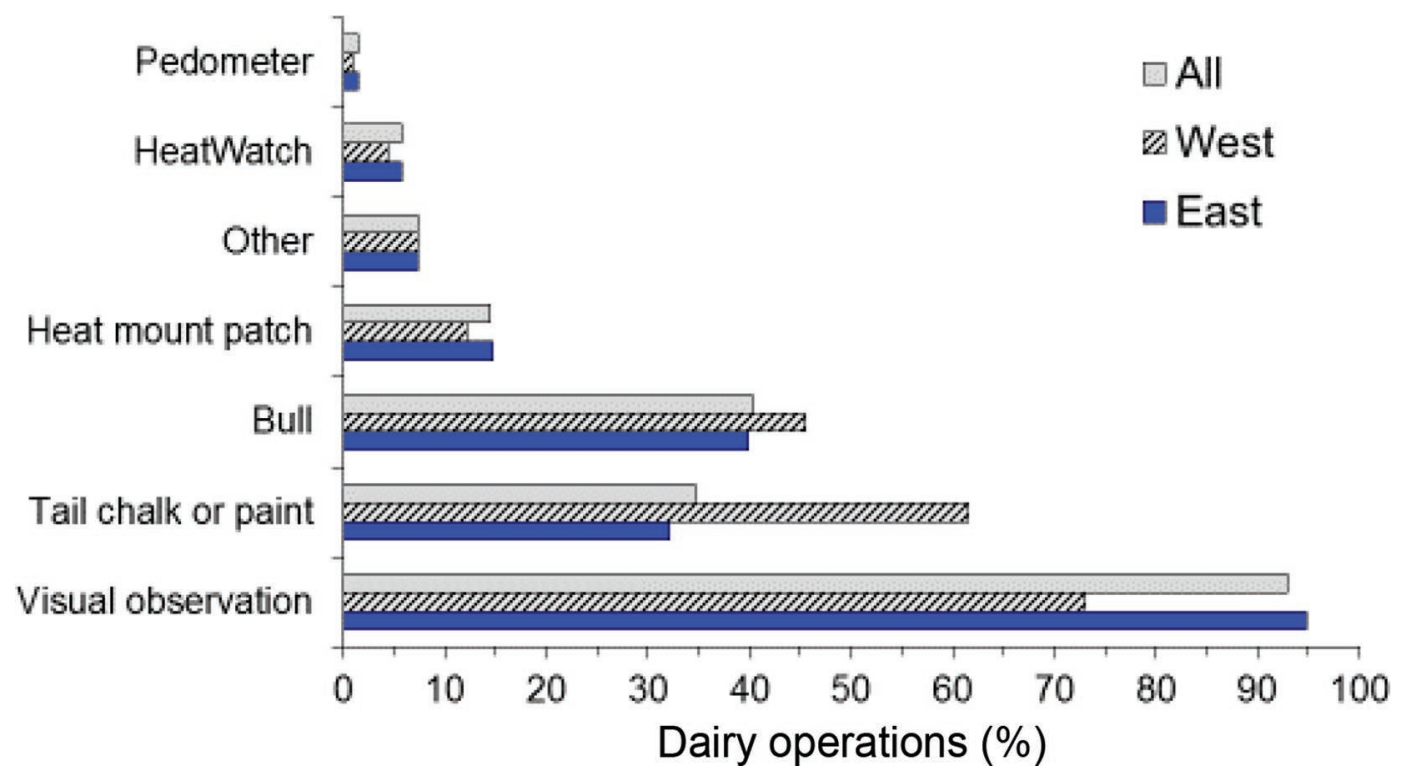

Figure 4. Percentage of US dairy operations by region using various estrus detection methods during 2006 (Source: NAHMS, 2007). HeatWatch is produced by CowChips LLC (Manalapan, NJ). Color version available online. 
pedometry or activity monitors, pressure-sensitive, rump-mounted radiotelemetric devices, temperature sensors, and milking inline chemical sensors.

Early in the 21st century, neck-mounted activity tags containing a microprocessor and a 3-dimensional accelerometer became available for detection of estrus. An accelerometer allows accurate measurement of cow movement. Activity tags monitor specific estrus-related movement and its intensity, resulting in detection accuracies up to 90\% (Roelofs et al., 2010). By 2010, the bestselling system in the world with approximately 1 million estrus-detection tags sold demonstrated that dairy farmers were willing to invest in technologies that provide a real solution to detection of estrus. Since the NAHMS survey in 2007 (Figure 4), at least a dozen companies are now offering activity monitor technology for use in dairy operations and will likely have a larger impact in dairy operations seeking for low-cost methods of identifying cows in estrus (Nebel, 2015). Some of the newest activity monitors in the market are equipped to monitor ear temperature, resting or lying time, rumination or feeding time. Some have global positioning sensor (GPS) capabilities to help locate individual cows in large pens. When integrated with daily milk production data, managers have the tools to monitor health and activity associated with estrus. Regardless of methods applied, visual detection of estrus has been the gold standard management practice upon which a successful AI program is built.

These activity systems are effective management tools in AI programs because their use can increase estrus-detection rates. Greater estrus-detection rates increase AI submission rates and more potential pregnancies. Several within-herd studies demonstrated that using activity monitors to detect estrus before AI compared with timed AI programs applied to control cows resulted in similar pregnancy risk (Neves et al., 2012; Stevenson et al., 2014; Denis-Robichaud et al., 2016)

Despite the increase in estrus-detection rates, 2 recent studies indicated that only 70 to $75 \%$ of dairy cows validated by progesterone concentration and transrectal ultrasonography of ovarian structures to have had luteolysis were detected in estrus by activity monitors (Valenza et al., 2012; Sauls et al., 2017). Furthermore, more than $50 \%$ of the cows not detected by the activity monitors ovulated in the absence of detected estrus.

Video systems have also been investigated to capture activity in freestall barns (Bruyère et al., 2012), but the cost and practicality of such systems require further study. Devices have been patented that claim to detect ovulation by changes in body temperature via an implanted temperature sensor or an implanted vaginal telemetry system that apparently detects tissue impedance, temperature, and activity of the animal.
Radio-telemetered monitoring of vaginal or ear skin temperature was accomplished with greater than $80 \%$ accuracy of detection and only a few false positives (Roelofs et al., 2010).

\section{Al Breeding Programs: Development of Timed Al}

Timed AI programs were used (NAHMS, 2007) to manage reproduction in at least some of the heifers and cows by $58.2 \%$ of operations (survey of 17 of major US dairy states representing $79.5 \%$ of US dairy operations and $82.5 \%$ of US dairy cows) with a greater percentage of using timed AI for cows (57.6\%) than for heifers $(25.4 \%)$. More than $60 \%$ operations had used timed AI for 5 yr or more. Regarding reasons for using timed AI, the greatest percentage of operations (48.8\%) used timed AI occasionally during the previous 12 mo to catch up on nonpregnant cows, and the reason that timed AI was used by the second greatest percentage of operations was to control all first and subsequent services $(27.7 \%)$. In another 103-herd survey, the majority of large US dairy operations $(>500$ cows; Caraviello et al., 2006) used timed AI programs almost exclusively to inseminate their cows. More than $85 \%$ of those large herds surveyed were using timed AI at first services after calving and $77 \%$ for resynchronizing repeat services.

Hormone-based timed AI breeding programs have been commonplace in the dairy industry since the late 1990s. Although the discovery in the early 1970s that $\mathrm{PGF}_{2 \alpha}$ is the natural uterine luteolysin in cattle, its use on dairy operations was originally limited to inducing estrus for first AI services (Britt et al., 1981) or inducing estrus in cows diagnosed not pregnant but having a palpable corpus luteum (CL; Plunkett et al., 1984). Injections of $\mathrm{PGF}_{2 \alpha}$ successfully regressed the $\mathrm{CL}$, with the majority of estrus activity occurring on $\mathrm{d} 2$ through 5 after treatment with $\mathrm{PGF}_{2 \alpha}$. Early in its application, 2 injections of $\mathrm{PGF}_{2 \alpha}$ were given 11 to $14 \mathrm{~d}$ apart to allow cows to be inseminated at detected estrus after the first injection and follow through with the second injection for all noninseminated cows. Waiting 11 to 14 $\mathrm{d}$ before reinjecting noninseminated cows allowed for some of the remaining cows to have a $\mathrm{PGF}_{2 \alpha}$-sensitive $\mathrm{CL}$ (not responsive to the first injection) or for the remaining cows to develop a new $\mathrm{PGF}_{2 \alpha}$-sensitive CL. The latter group of cows was most likely those that responded (CL regression) to the first $\mathrm{PGF}_{2 \alpha}$ injection but were not detected in estrus. These simple programs are still common in southwest and western dry-lot dairies in which rates of detected estrus average greater than $70 \%$.

Variation in the interval to estrus after $\mathrm{PGF}_{2 \alpha}$ was not understood until application of transrectal ultra- 
sonography to monitor growth patterns of individual follicles during the mid-1980s (see Thatcher, 2017). It was discovered that follicles emerge together every 8 to $10 \mathrm{~d}$ (a follicle wave) with cows having 2 or 3 follicular waves per estrous cycle. Based on understanding of normal follicular wave dynamics of the estrous cycle, brought about by using transrectal ultrasonography, it became clear that synchronizing follicle growth must be coupled with induced regression of the CL to better synchronize subsequent ovulation.

As early as 1983, it was known that giving GnRH $3 \mathrm{~d}$ after $\mathrm{PGF}_{2 \alpha}$ would enhance synchronized ovulation and subsequent pregnancy risk (Lucy and Stevenson, 1986), but it was not recognized until the 1990s that GnRH administered before $\mathrm{PGF}_{2 \alpha}$ to dairy heifers and cows could synchronize follicular development before lysing the CL with $\mathrm{PGF}_{2 \alpha}$ (Twagiramungu et al., 1995), thus resulting in various successful timed AI programs used on dairy operations (Wiltbank and Pursley, 2014).

\section{Timed Al Programs Before First Service}

Ovsynch. A history of the most commonly applied timed AI program (Ovsynch) in dairy cows is available elsewhere (Wiltbank and Pursley, 2014). Among versions of Ovsynch, the most commonly used is the 7-d Ovsynch scheme (Figure 5A, 5B, and 5C). Variations of this scheme include a 5 -d program with doses of $\mathrm{PGF}_{2 \alpha}$ given on $\mathrm{d} 5$ and 6 and timed $\mathrm{AI}$ on $\mathrm{d} 8$ (0 to 16 $\mathrm{h}$ after the second GnRH injection; Figure 5D). Insight is provided in detail in recent reviews (Bisinotto et al., 2014; Stevenson, 2016).

Presynch $\boldsymbol{P} \boldsymbol{G F}_{2 \alpha}$ Programs. Early studies indicated that pregnancy outcomes at first AI might be
A.

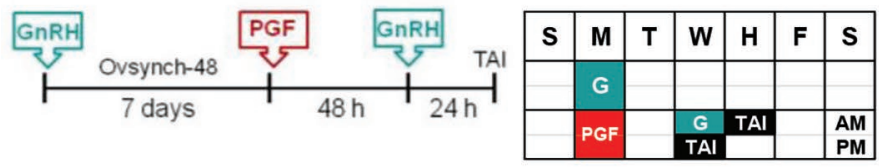

C.

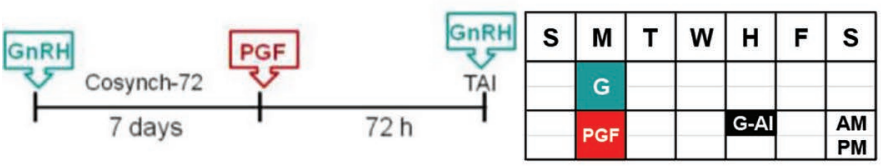

E.
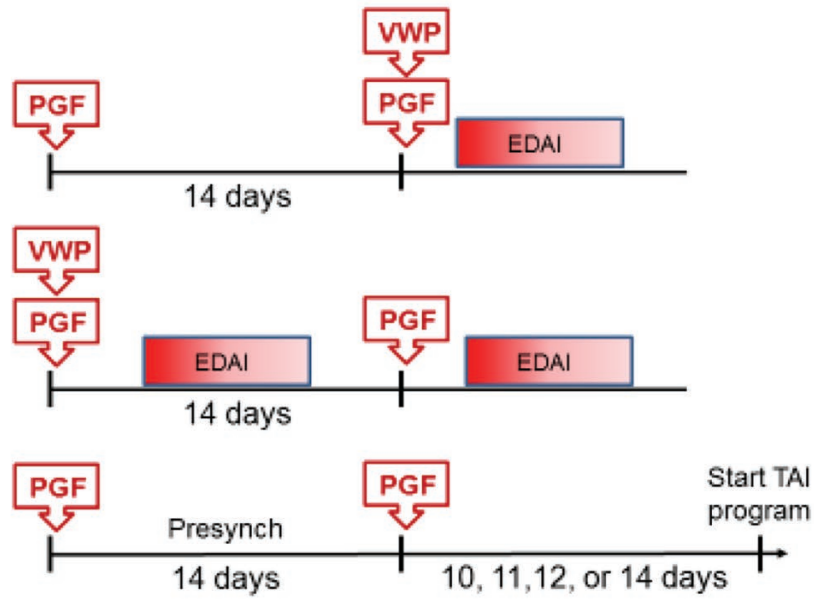

B.

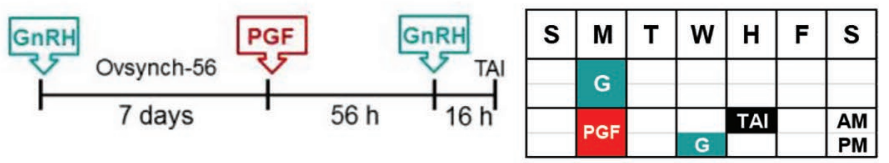

D.

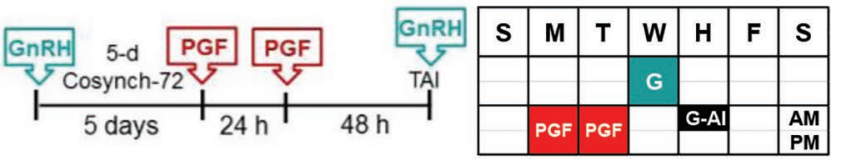

F.
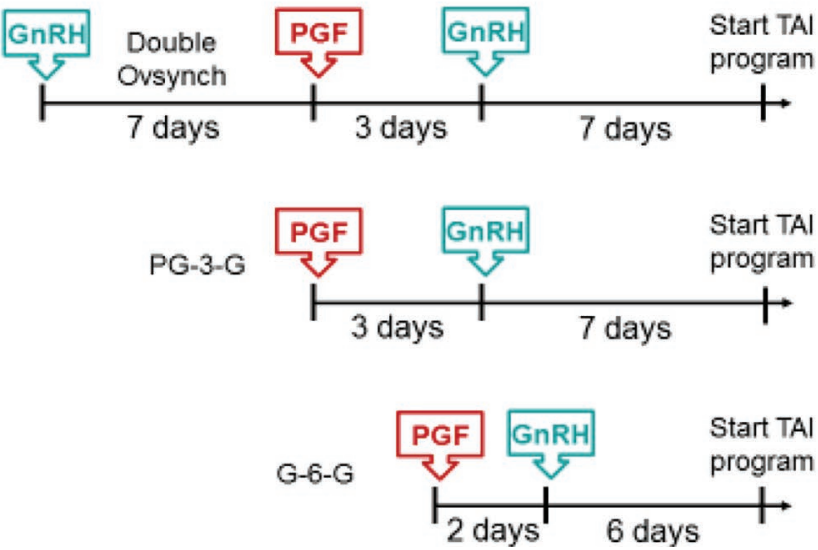

Figure 5. The basic ovulation-synchronization timed AI (TAI) program is known as Ovsynch. It consists of a GnRH injection (G; $100 \mu \mathrm{g})$ to induce an LH surge to cause ovulation followed in $7 \mathrm{~d}$ with $\mathrm{PGF}_{2 \alpha}$ (PGF) to lyse the corpora lutea (CL) before a second dose of GnRH is administered at $48 \mathrm{~h}$ (A; Ovsynch-48), $56 \mathrm{~h}$ (B; Ovsynch-56), or $72 \mathrm{~h}$ (C; Cosynch-72) after $\mathrm{PGF}_{2 \alpha}$. An alternative short version is a 5-d program (D; 5-d Cosynch-72) in which 2 doses of PGF are necessary to lyse any new CL that formed after GnRH. Progesterone supplementation can be applied via an intravaginal progesterone-releasing controlled internal drug release (CIDR) insert during the interim between GnRH and PGF. For first services after calving, cows can be treated with either 1 or 2 PGF injections administered $14 \mathrm{~d}$ apart and then inseminated after detected estrus (E; EDAI) or presynchronize estrous cycles by $2 \mathrm{PGF}_{2 \alpha}$ injections before any timed AI programs (A, B, C, or D) at first services. Other presychronization treatments before first services can include $\mathrm{GnRH}$ and $\mathrm{PGF}_{2 \alpha}(\mathrm{F})$ before any timed AI programs $(\mathrm{A}, \mathrm{B}, \mathrm{C}$, or D) at first services. VWP = voluntary waiting period. Color version available online. 
improved when cows were at specific stages of an estrous cycle at initiation of the timed AI program. Cows beginning the timed AI program on d 5 through 12 of their estrous cycles had greater ovulatory responses to the first $\mathrm{GnRH}$ injection and greater fertility than cows at other stages of the cycle (Vasconcelos et al., 1999). Thus, 2 research groups tested whether estrous cycles could be staged to meet this ideal by applying 2 injections of $\mathrm{PGF}_{2 \alpha}$ administered $14 \mathrm{~d}$ apart and then initiating the timed AI program 12 d later (named Presynch-12; Figure 5E). Their so-called Presynch treatment before Ovsynch resulted in greater pregnancy outcomes after first services compared with applying only Ovsynch to cows at random stages of their estrous cycles (Moreira et al., 2001; El-Zarkouny et al., 2004). A Presynch-14 program also was superior to Ovsynch alone for timed AI pregnancy outcome (Navanukraw et al., 2004).

Other permutations of the original Presynch have been applied (e.g., Presynch-14, Presynch-11, and Presynch-10) in which the 2 injections of $\mathrm{PGF}_{2 \alpha}$ were consistently administered $14 \mathrm{~d}$ apart, but the interval between the last injection to the onset of the timed AI program was 14, 11, or $10 \mathrm{~d}$, respectively (Figure 5E). The interval between the second Presynch $\mathrm{PGF}_{2 \alpha}$ injection and the onset of Ovsynch determines the stage of the cycle at the onset of Ovsynch with decreasing days from the second Presynch $\mathrm{PGF}_{2 \alpha}$ injection resulting in earlier stages of the cycle at the onset of Ovsynch when a dominant follicle is capable of ovulating after GnRHinduced LH release (Vasconcelos et al., 1999).

In nearly all published studies, these Presynch $\mathrm{PGF}_{2 \alpha}$ systems have produced improved pregnancy outcomes compared with outcomes in cows submitted to the timed AI program at random stages of the estrous cycle without Presynch (Stevenson, 2016). Overall, lactating dairy cows exposed to Presynch $\mathrm{PGF}_{2 \alpha}$ programs have $42 \%$ greater odds of pregnancy compared with cows receiving only the timed AI program (Bisinotto et al., 2014). Furthermore, improved pregnancy outcomes were reported in cows treated with Presynch-11 than Presynch-14 before a timed AI program (Stevenson, 2016), probably because more cows were at the ideal stage of the cycle after Presynch-11 treatment (d 6 to 9 vs. d 9 to 12, respectively). Further reducing the interval between Presynch and Ovsynch, however, may reduce pregnancy outcomes. An additional benefit of Presynch $\mathrm{PGF}_{2 \alpha}$ programs is the flexibility of choosing to inseminate cows detected in estrus after $\mathrm{PGF}_{2 \alpha}$ rather than waiting to inseminate after the Ovsynch program (Figure 5E; Stevenson, 2016).

Presynch GnRH Programs. A major limitation to Presynch $\mathrm{PGF}_{2 \alpha}$ programs is their inability to improve fertility in anovular cows - those which have not initiated estrous cycles after calving - which may represent up to $41 \%$ of dairy cows at the end of the VWP (Bisinotto et al., 2014). Newer presynchronization systems that include GnRH administration in addition to injections of $\mathrm{PGF}_{2 \alpha}$ increase the odds for pregnancy by 1.65 times (Bisinotto et al., 2014) and have resulted in 3 different schemes: GnRH-7 d-PGF ${ }_{2 \alpha}-3$ d-GnRH (Double Ovsynch); $\mathrm{PGF}_{2 \alpha}-3$ d-GnRH (PG-3-G); and $\mathrm{PGF}_{2 \alpha}-2$ d-GnRH (G-6-G) (Figure 5F). In some cases, Double Ovsynch and PG-3-G may improve pregnancy outcomes compared with the 2 standard Presynch $\mathrm{PGF}_{2 \alpha}$ variants (Presynch-12, Souza et al., 2008; and Presynch-10, Stevenson and Pulley, 2012). The PG3-G program produced better timed AI pregnancy outcomes during summer than Presynch-10 (Stevenson and Pulley, 2012). These Presynch-GnRH programs cause a larger proportion of cows to be at the most ideal stage of the cycle to initiate Ovsynch (d 6 to 8). Based on a meta-analysis considering 27 herds and 9,813 AI, cows with $100 \%$ timed AI after completing a $\mathrm{PGF}_{2 \alpha}$ Presynch-Ovsynch program at first service had more pregnancies compared with cows that were inseminated after detected estrus or received timed AI for cows showing no signs of estrus (Borchardt et al., 2016). In a second meta-analysis, comparing presynchronization programs with or without GnRH before timed AI, benefit was detected for pregnancy outcomes in primiparous cows presynchronized with a PresynchGnRH program at first service, but this benefit was not observed in multiparous cows (Borchardt et al., 2017).

Improved pregnancy outcomes of Presynch GnRH programs may be realized in herds where more cows are anovulatory because more total cows ovulate in response to both GnRH injections of Ovsynch. Thus, Presynch options that include $\mathrm{GnRH}$ administration increase opportunities for anovulatory cows to ovulate either before or in response to the timed AI program. In addition, cows that lack a CL at the first GnRH administration of the timed AI program, which includes anovular or cycling cows treated during proestrus, estrus, and metestrus, have reduced concentrations of progesterone compared with cows with a CL. These groups of cows may represent approximately 30 to $40 \%$ of cows subjected to timed AI and are those that have the poorest pregnancy outcomes. In fact, cows without a CL treated experimentally with 2 CIDR inserts at the beginning of Ovsynch had similar pregnancy risk as contemporary cows starting Ovsynch in diestrus with a CL (see Bisinotto et al., 2014).

Presynch Five-Day Programs. Ovulation in response to the first GnRH injection of Ovsynch improves synchronization of the estrous cycle and reduces the period of follicular dominance; both factors may be associated with improved pregnancy outcomes (Vasconcelos 
et al., 1999; Santos et al., 2010). One limitation to the 5 -d program is the inability of a single dose of $\mathrm{PGF}_{2 \alpha}$ to induce complete CL regression in all cows (particularly a "new" CL that resulted from GnRH-induced ovulation). Therefore, 2 doses of $\mathrm{PGF}_{2 \alpha}$ are required (one on d 5 and another on d 6; Figure 5D) to optimize luteal regression by either $\mathrm{PGF}_{2 \alpha}$ or by one of its analogs. Recent studies included the addition of a second dose of $\mathrm{PGF}_{2 \alpha}$ in the 7 -d program $\left(\mathrm{PGF}_{2 \alpha}\right.$ on $\mathrm{d} 7$ and 8$)$ compared with a 5 -d program $\left(\mathrm{PGF}_{2 \alpha}\right.$ on $\mathrm{d} 5$ and 6$)$ and reported inadequate luteolysis in cows receiving only $1 \mathrm{PGF}_{2 \alpha}$ on d 7 (Santos et al., 2016). Furthermore, addition of a second dose of $\mathrm{PGF}_{2 \alpha}$ in a multi-herd 7-d Ovsynch study increased luteolysis from 83 to $97 \%$, but only increased pregnancy risk by 3 percentage points (Wiltbank et al., 2015).

Dose of $\boldsymbol{G n R H}$. Increasing doses of $\mathrm{GnRH}$ in 7-d Ovsynch programs have increased LH responses to GnRH injections of Ovsynch (Giordano et al., 2012a), but did not increase the percentage of cows ovulating or the percentage of inseminated cows that became pregnant (Giordano et al., 2013).

Timing of GnRH. For 7-d programs, optimal timing of the second (or breeding) injection of $\mathrm{GnRH}$ to produce the greatest pregnancy risk is approximately $56 \mathrm{~h}$ after $\mathrm{PGF}_{2 \alpha}$ (Ovsynch-56; Figure 5B), with AI occurring approximately $16 \mathrm{~h}$ later (at $72 \mathrm{~h}$ ) compared with timed AI at either 48 or $72 \mathrm{~h}$, concurrent with the second $\mathrm{GnRH}$ injection (Figure $5 \mathrm{~A}$ or $5 \mathrm{C}$ ). In contrast, for cows subjected to the 5-d Ovsynch program, which results in smaller ovulatory follicles and reduced concentrations of estradiol in the plasma around the time of AI compared with the 7-d Ovsynch program, the duration of proestrus should be extended to $72 \mathrm{~h}$, so the second GnRH injection and timed AI should occur at 72 after $\mathrm{PGF}_{2 \alpha}$ (Stevenson, 2016).

Programs Including Progesterone. Progesterone treatment with the CIDR insert has been used in some timed AI programs since its US market availability in 2003. The CIDR is either applied intravaginally for 5 or $7 \mathrm{~d}$ with an injection of $\mathrm{PGF}_{2 \alpha}$ upon insert removal or in combination with Ovsynch (inserted when the first $\mathrm{GnRH}$ is administered and removed 5 or $7 \mathrm{~d}$ later at the time of $\mathrm{PGF}_{2 \alpha}$ injection). About one-third of dairy operations (32.4\%) used CIDR inserts during 2006 to treat anestrous females $(65.7 \%)$ or cows with ovarian cysts $(43.5 \%)$ or to synchronize estrus $(34.3 \%)$ in females (NAHMS, 2007).

A review of the literature including a meta-analysis indicated that use of a single CIDR insert administered during the period between the first $\mathrm{GnRH}$ injection and the $\mathrm{PGF}_{2 \alpha}$ of the timed AI program increased the percentage of pregnant cows at d 60 after AI compared with untreated controls, and the benefit from pro- gesterone supplementation was similar for cows with and without a CL (Bisinotto et al., 2015). In general, pregnancy risk in that summary was greater for cows treated with progesterone than for controls. Nevertheless, pregnancy risk for cows without CL treated with a single insert was 10.5 percentage points less than that of untreated cows that had a CL at the initiation of the timed AI program.

Cows benefitting the most from supplemental progesterone were those that were anovular or not in diestrus at the onset of the timed AI program. Incorporating 1 or 2 progesterone inserts as part of a timed AI program increased fertility in cows that lacked a CL at the first $\mathrm{GnRH}$ injection, but did not restore fertility to the same level as those cows starting the timed AI program in diestrus (reviewed by Stevenson, 2016).

\section{Resynchronization Programs}

Not-Pregnant Diagnosis. Increased efficiency of reproduction occurs when pregnancy status in previously inseminated cows is determined as soon as possible. When $\mathrm{PGF}_{2 \alpha}$ was introduced in 1979 , a common practice of treating nonpregnant cows was to inject $\mathrm{PGF}_{2 \alpha}$ when a palpable CL was found upon not-pregnant diagnosis (NPD). Cows were either inseminated upon detected estrus or by appointment at 72 and $96 \mathrm{~h}$ after $\mathrm{PGF}_{2 \alpha}$ (Plunkett et al., 1984). When inseminations only occurred after detected estrus, failing to follow up on noninseminated cows resulted in nonpregnant cows remaining uninseminated for variable periods until they were detected in estrus.

Once timed AI programs such as Ovsynch became in vogue, studies were conducted using timed AI programs initiated in nonpregnant cows starting either a 5- or 7-d resynchronization (Resynch)-Ovsynch program on the day of NPD. When using transrectal ultrasonography to diagnose pregnancy on a weekly basis, it is common to evaluate cows that were inseminated 30 to $36 \mathrm{~d}$ before the NPD. If the NPD falls on a Monday, then most cows that received a timed AI on Thursday would be at d 32 of pregnancy. If transrectal palpation were used for pregnancy diagnosis, then a common interval for days since last AI would fall between d 37 and 43, with most cows receiving a timed AI on d 39.

Presynchronization Before Resynch. In some herds, cows diagnosed not pregnant are started on a timed AI program on the day of NPD. In other herds, to reinseminate cows sooner after a NPD, the first GnRH injection of the timed $\mathrm{AI}$ is administered to all cows eligible for the next pregnancy diagnosis (unknown pregnancy status) either 5 or $7 \mathrm{~d}$ before NPD depending on which timed AI program is used (i.e., 5 vs. 7 d). Applying a presynchronization treatment 
such as GnRH or human chorionic gonadotropin (hCG) to induce ovulation and initiate a new follicular wave in cows of unknown pregnancy status has been tested for its profertility effects. Simple Resynch-Ovsynch programs initiated at d 32 or 39 after previous AI were compared with treatments that included a presynchronization $\mathrm{GnRH}$ or $\mathrm{hCG}$ injection administered $7 \mathrm{~d}$ before the NPD and the initiation of Ovsynch. At both initiation times, the pre-GnRH or pre-hCG injection increased pregnancy risk by 4 to 5 percentage units (Dewey et al., 2010; Giordano et al., 2012b,c; Bruno et al., 2014).

Addition of progesterone to such treatments in nonpregnant cows in designed studies in 7-d ResynchOvsynch programs initiated at the NPD failed to increase pregnancy risk of cows, whereas when tested in a 5-d Ovsynch program initiated at d 32, progesterone increased pregnancy outcome (Bisinotto et al., 2010). As previously noted, the greatest pregnancy advantage accrues from applying progesterone to cows without a CL rather than those with a CL.

In the early Resynch studies, detection of estrus was not applied in those designs, thus all cows received only a timed AI. In herds applying regular estrus detection, a large proportion of cows may be detected in estrus subsequent to the NPD. Therefore, in more recent studies, cows at NPD either received $\mathrm{PGF}_{2 \alpha} 7$ or $11 \mathrm{~d}$ before initiating a Resynch-Ovsynch or a GnRH injection was administered as a presynchronization treatment $7 \mathrm{~d}$ before NPD as a control. In 2 such studies (Silva et al., 2007; Bruno et al., 2013), fewer cows were detected in estrus and inseminated before the timed AI program was initiated when the presynchronization GnRH injection was applied compared with the control Resynch $+\mathrm{PGF}_{2 \alpha}$ that included AI of cows after detected estrus. Although overall resulting pregnancy risks did not differ, cows detected in estrus and inseminated became pregnant sooner after the NPD than timed AI cows (Chebel et al., 2013). In general, when applying Resynch programs to dairy cows at NPD, employing presynchronization $\mathrm{PGF}_{2 \alpha}$ facilitates estrus expression, whereas using a pre-GnRH injection suppresses estrus expression.

\section{Replacement Heifer Al-Breeding Programs}

When heifers are inseminated after detected estrus without any hormone synchronization, it is common for conception risk to exceed $60 \%$. Even when inseminations are performed after $\mathrm{PGF}_{2 \alpha}$ injections (and the majority of heifers express estrus on $\mathrm{d} 2$ through 5 after injection) and inseminations are made after detected estrus, conception risk is commonly greater than $60 \%$. These are traditional and proven programs for heifers, but they require time and skilled labor for detection of estrus. In large groups of heifers, such as found in heifer grower operations, inseminations are often based on both estrus and timed AI programs, followed by cleanup bulls. Sex-sorted semen is often used when inseminating replacement heifers, limiting conception risk to approximately 70 to $80 \%$ of what is achieved with conventional semen (DeJarnette et al., 2009).

Seven-Day Programs. When applying timed AI in heifers, pregnancy risk will be slightly reduced to the mid-50\% range compared with insemination following detected estrus. The benefit of not needing estrus detection expertise, however, makes timed AI of heifers attractive for many heifer developers. A 7-d timed AI program in heifers includes a progesterone insert (e.g., CIDR) used for $7 \mathrm{~d}$ and $\mathrm{PGF}_{2 \alpha}$ injected upon its removal, in addition to a GnRH injection at CIDR insertion and a second $\mathrm{GnRH}$ injection between the $\mathrm{PGF}_{2 \alpha}$ injection and timed AI. Similar conception is expected for the 7-d CIDR programs when heifers are inseminated after detected estrus up until $72 \mathrm{~h}$ after $\mathrm{PGF}_{2 \alpha}$ and then the remaining heifers are injected with GnRH and inseminated at $72 \mathrm{~h}$ in the absence of estrus.

Five-Day Programs. The most consistent results for timed AI in heifers are found using the 5-d timed AI programs (Figure 6). A series of recent studies conducted in a large number of dairy heifers examined some variations of the 5 -d timed AI program. In study 1 (Figure 6), ovulation in dairy heifers was synchronized and injections of $\mathrm{PGF}_{2 \alpha}$ were administered on $\mathrm{d}$ 5 (one when the CIDR insert was removed and another $12 \mathrm{~h}$ later). Pregnancy risk did not differ in 2 separate experiments, but ranged from 53 to $59 \%$ (Rabaglino et al., 2010a).

In study 2 (Figure 6), a comparison was made between using 1 or $2 \mathrm{PGF}_{2 \alpha}$ injections at the time of CIDR insert removal. No differences in pregnancy risk were detected in 2 experiments (Rabaglino et al., 2010b).

In study 3 (Figure 6), only $1 \mathrm{PGF}_{2 \alpha}$ injection was employed and the researchers addressed the need for the GnRH-1 injection. Results from study 3 showed no advantage in using the GnRH-1 injection when 1 $\mathrm{PGF}_{2 \alpha}$ injection was administered because pregnancy risks ranged from 48 to $52 \%$ (Lima et al., 2011).

In study 4 (Figure 6), no GnRH-1 injection was used with only $1 \mathrm{PGF}_{2 \alpha}$ injection and the proper timing of GnRH-2 was tested. Results showed that the inconvenience of handling the heifers an extra time to administer GnRH-2 at $56 \mathrm{~h}$ (16 h before the timed AI) was not necessary to maximize pregnancy risk. In contrast, for those heifers that did not show estrus during the $72 \mathrm{~h}$ after $\mathrm{PGF}_{2 \alpha}$ and CIDR removal, extending the time to the $\mathrm{GnRH}$ injection to $72 \mathrm{~h}$ (coincident with the timed 


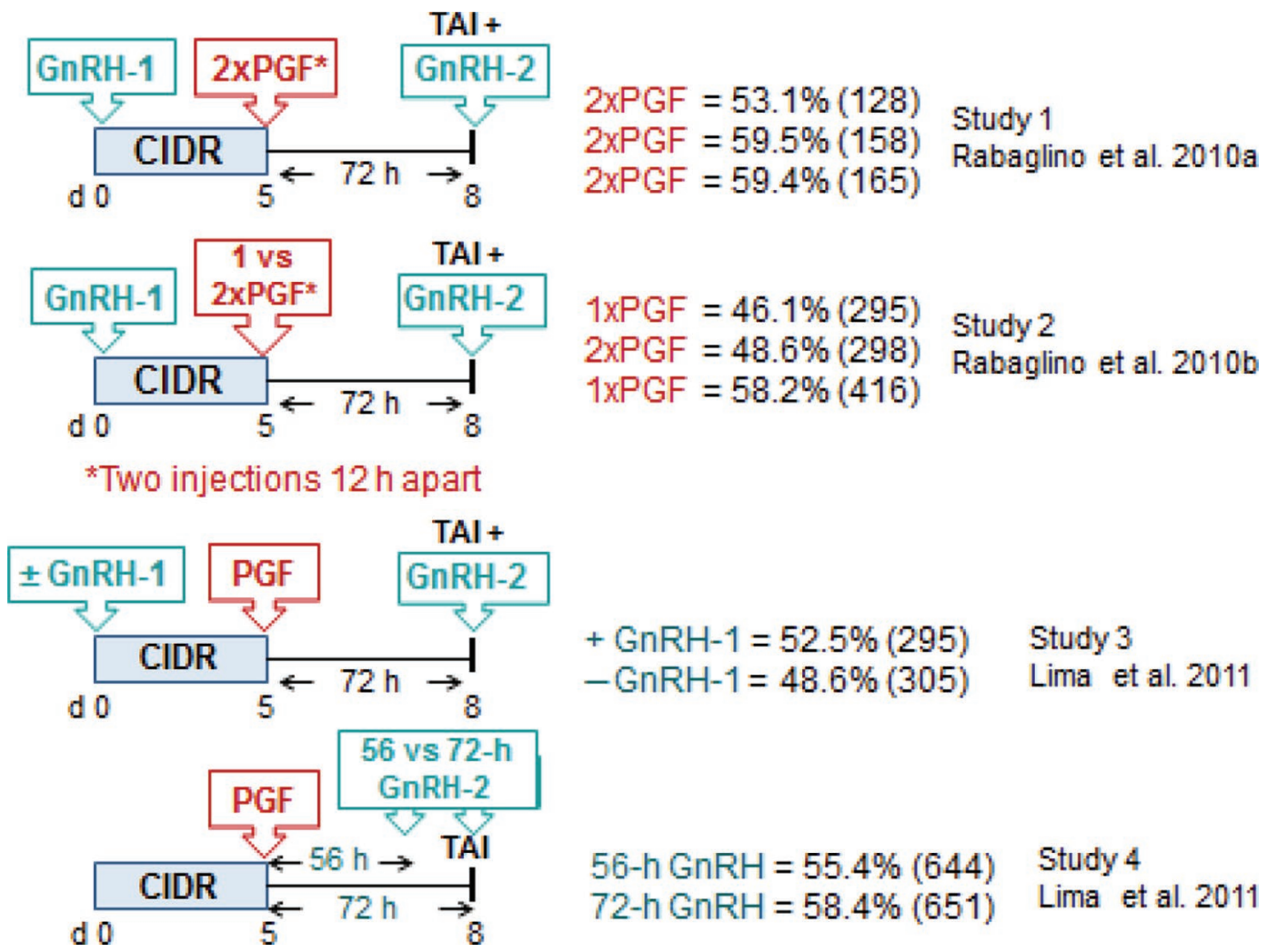

Figure 6. Variations in 5-d timed AI programs for replacement heifers are discussed in the text. CIDR $=$ controlled internal drug release progesterone insert; $\mathrm{PGF}=\mathrm{PGF}_{2 \alpha} ; \mathrm{TAI}=$ timed $\mathrm{AI}$. Color version available online.

AI) improved their pregnancy outcome from 44.7 to $53 \%$ (Lima et al., 2011).

One further study demonstrated that when GnRH-1 was administered at the time of CIDR insertion in a 5-d program, administering $2 \mathrm{PGF}_{2 \alpha}$ injections (24 h apart; one with CIDR insert removal and one $24 \mathrm{~h}$ later) was advantageous to improve pregnancy risk compared with not using GnRH-1 and using only one $\mathrm{PGF}_{2 \alpha}$ injection (Figure 6).

In summary, synchronization of ovulation in dairy heifers by using a progesterone insert with administrations of $\mathrm{GnRH}$ and $\mathrm{PGF}_{2 \alpha}$ in 5 -d programs can be successful. The results indicated that the 5 -d program is effective and the GnRH-1 injection is not necessary when using only $1 \mathrm{PGF}_{2 \alpha}$ injection. Extending the timing of the GnRH-2 to $72 \mathrm{~h}$ (coincident with the timed AI) benefitted heifers that did not show estrus during the $72 \mathrm{~h}$ after CIDR insert removal.

\section{Pregnancy Diagnosis}

Pregnancy exams are used on dairy operations to identify pregnancy status of inseminated or mated females. Because the majority of US dairies operate a continuous 365-d breeding season and cows calve year- round, it is critical to determine pregnancy status and identify nonpregnant cows so that they can be managed and reinseminated in a timely manner to reduce interinsemination and calving intervals. Additional benefits of pregnancy exams include detection of uterine or ovarian abnormalities, diagnosis of twins, and estimation of conception and calving dates for females with unobserved natural service by bulls.

In the 1800s, transrectal palpation of the uterus and its contents was first identified as a method of pregnancy diagnosis. Traditional diagnosis of pregnancy involves palpation of the conceptus (detection of fluidmembrane slip, or amniotic vesicle, or both) between 35 and $40 \mathrm{~d}$ after last insemination or mating. About twothirds of all dairy operations $(67 \%)$ performed pregnancy exams monthly or more frequently during 2006 (NAHMS, 2007). The majority of large (>500 cows) operations $(75 \%)$ performed pregnancy exams weekly or every $2 \mathrm{wk}$, whereas $50 \%$ of smaller operations $(<100$ cows) performed exams on a monthly basis. Transrectal palpation is the method used most routinely to determine pregnancy status (85.7\%), with the residual using transrectal ultrasonography $(27.4 \%)$ and the blood test for assessing concentrations of pregnancy-associated glycoproteins $(4.1 \%)$. Of dairy operations surveyed in 
2014 (NAHMS, 2014), 85.7\% used a veterinarian as a reproductive consultant.

A recent review (Fricke et al., 2016) highlighted current methodologies and implementation of pregnancy diagnosis in dairy cattle. Transrectal ultrasonography is becoming more accepted because portable, batterypowered units are available. Evidence of a viable embryo can be detected as early as $20 \mathrm{~d}$ in heifers, but accuracy and efficiency are best in routine herd exams for cows that are at least 28 to $30 \mathrm{~d}$ since last insemination.

Use of ultrasonography requires skill and training. Common errors include a false-positive diagnosis of uterine intraluminal fluid that is associated with estrus and not with the presence of a conceptus. On-farm ultrasonography is also diagnostic in assessing follicular structures (differentiating between follicular and luteal cysts), functional CL, twins, embryonic loss, and fetal sexing (Fricke, 2002). A major advantage of applying ultrasound is earlier and more accurate detection of pregnancy, which has great effect on reproductive management of dairy herd.

Pregnancy-specific proteins are produced by the conceptus during early pregnancy, and one class of these proteins is called pregnancy-associated glycoproteins (PAG; Ricci et al., 2015). Concentrations of PAGs are detectable approximately $25 \mathrm{~d}$ after AI, reach a peak near d 32, decrease to nadir by d 60 , and then increase to greater concentrations throughout the remainder of gestation (Figure 7). Because of the described pattern in plasma and milk PAG profiles, the optimal time to conduct a first pregnancy diagnosis is approximately $32 \mathrm{~d}$ after AI, coinciding with an early peak in PAG concentrations (Ricci et al., 2015). Furthermore, because of the occurrence of pregnancy loss, all pregnant cows should be retested $74 \mathrm{~d}$ after AI or later, when plasma and milk PAG concentrations in pregnant cows have rebounded from their nadir. Although application of blood tests to identify PAGs was done on a minority of dairy operations in a recent survey (NAHMS, 2007), its use has increased greatly since then. At least 3 companies in North America are marketing the blood tests, which are routinely performed in veterinary clinics or other labs with a 24- to 36-h turnaround. One company also assays PAG milk samples. Incorporating these tests in reproductive programs usually involves collecting a blood or milk sample at 28 to $32 \mathrm{~d}$ after last insemination. The blood sample can be collected when a resynchronization program is initiated (first $\mathrm{GnRH}$ injection of the Ovsynch program is administered) so the program can be continued $7 \mathrm{~d}$ later when the notpregnant status of the female is confirmed. Alternately, Resynch-Ovsynch is simply initiated after the blood or milk test results become available. These tests are relatively inexpensive, as accurate as transrectal ultra-

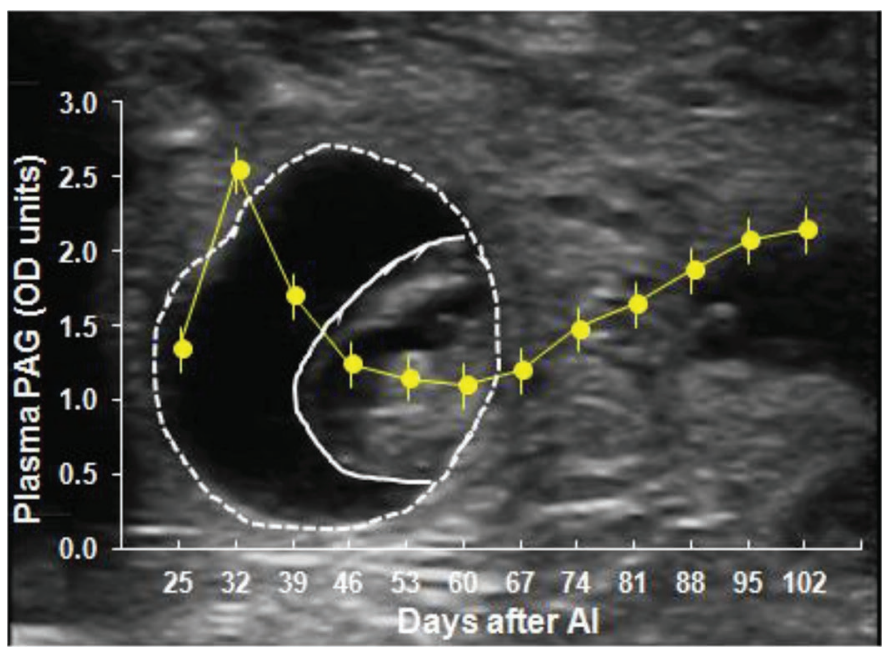

Figure 7. Plasma concentrations of pregnancy-associated glycoprotein (PAG) from 25 to $102 \mathrm{~d}$ of pregnancy are superimposed on an ultrasonogram of a 30-d bovine conceptus (solid line) suspended in a cross-section of a uterine horn (dashed line). The PAG data are from Ricci et al. (2015). OD = optical density. Color version available online.

sonography diagnoses made by skilled technicians, and do not require expensive equipment or skilled training. Many of the DHI labs offer the PAG test as a service to dairy producers.

Because pregnancy is diagnosed by ultrasonography or blood or milk tests before some natural spontaneous embryo losses occur, later verification of a viable pregnancy is essential. Losses of embryos identified as viable on $\mathrm{d} 28$ can be up to 10 to $15 \%$ during the next 4 to 6 wk (Santos et al., 2004). If pregnancy was first detected at 35 to $45 \mathrm{~d}$ after last AI, some of these losses would never have been detected if the first diagnosis occurred after $45 \mathrm{~d}$. For these reasons, it is recommended that early pregnancy diagnoses be verified later, perhaps by 80 to $100 \mathrm{~d}$ after AI, mid gestation, and again before terminating the lactation to begin the dry period.

\section{Recombinant Bovine Somatotropin}

One of the first potential biotechnology products for animal production was bST. Discovered more than 70 yr ago, bST was reported to increase milk yield by $15 \%$ in lactating dairy cows regardless of stage of lactation (Bauman, 1992). It was later synthesized and produced for commercial use through recombinant DNA technology similar to procedures used to produce human insulin.

Recombinant DNA derived-bovine somatotropin (rbST) also increases milk production by 15\%. By 1978, research in the technology of bST involved hundreds of scientists publishing more than 1,000 studies involving more than 20,000 dairy cows. Treating cows with longacting rbST (once every $14 \mathrm{~d}$ ) not only increases milk 
production on commercial dairy farms today but it was also observed, in a few studies, to have positive effects on pregnancy outcomes of well-managed cows (Moreira et al., 2001). First treatment with bST at first services after calving following a timed AI program (Ovsynch) or upon detected estrus resulted in increased pregnancy rates and reduced early embryonic death between $\mathrm{d}$ 31 and 45 after AI (Moore and Thatcher, 2006). The mechanism of bST action includes improved fertilization rate, accelerated embryo development, improved embryo quality, and increased conceptus growth at the time pregnancy is recognized approximately 15 to $16 \mathrm{~d}$ after AI (Ribeiro et al., 2014). Use of rbST has waxed and waned since it first became publicly available in the United States in 1994 (Caraviello et al., 2006), in part because of misunderstandings by consumers about the science and safety of such products and reluctance of dairy processors to market milk products coming from dairy operations using rbST. Today, most cooperatives and processors have restricted its use within their supply chain. The percentage of operations and the percentage of cows for which rbST was used increased as herd size increased. Overall, $9.7 \%$ of operations used $\mathrm{rbST}$, and $14.7 \%$ of all cows received rbST during the most recent lactation (NAHMS, 2014).

\section{Management Software Applications}

Dairy record program software has been available for many years through the dairy record processing centers associated with the DHIA. The first DHI organizations were established in 1905 to provide a standardized method of collecting data from individual cows. Approximately $41 \%$ of US dairy operations participate in DHI testing programs, representing $47 \%$ of the 9.3 million dairy cows (NMPF, 2016). In the early days of DHI testing, summaries were prepared by hand, typed on forms, and sent to participating herds. Later, when computers came on line, print-outs were mailed to dairy producers within a few days of the monthly herd test summarizing milk yield, and various milk components (e.g., fat, protein, SCC, lactose, milk urea nitrogen) that were analyzed at DHI-affiliated laboratories. Daily yield of milk, milk component percentages, SCC, and other information such as calving and breeding dates, calf identification, pregnancy diagnoses, feed components and costs, culling information, and so on, are collated and entered into the software to produce the monthly printed reports.

In $2013,47.5 \%$ of dairy operations had access to the internet for dairy information. Internet use generally increased as herd size increased, with $31.6 \%$ of very small operations accessing the internet for dairy information compared with $89.7 \%$ of large operations
(NAHMS, 2014). Almost $100 \%$ of US dairies use onfarm computers that allow the same information to be collected, entered, and used in daily management routines in addition to measured milk and milk component data that occurs periodically. Each of the dairy record processing centers have their own unique software that shares most of the same output data in different formats for dairy producers. In addition, an independent software package used by many larger dairies is DairyComp 305 (Valley Agricultural Software, Tulare, CA). Another advantage of computerized records is to share that information with herd consultants and veterinarians who assist in closely monitoring client herd reproductive, production, and health issues. Consultants can easily obtain this information by obtaining a backup of each dairy's computer records or, with permission of the dairy producer, obtain a download from one of the dairy record processing centers.

Not only are computers commonplace but many dairy managers use handheld devices (including smartphones) that communicate with the farm computer to reveal needed information about cows as they work in cow pens. With the advent of electronic identification chips in radiofrequency identification (RFID) ear tags, cows can be identified by Bluetooth wands to retrieve various information about individual daily treatments. Milking equipment companies are now investing in inline milk monitoring equipment that can measure metabolites as well as progesterone concentrations in the milk of cows during the milking process and produce elegant profiles of milk progesterone to assist managers in determining reproductive status (cycling or pregnancy status) of individual cows (Østergaard et al., 2005). Use of computers, computer-generated reports, and access to electronic data at the fingertips of dairy managers has not only influenced production but also increased efficiency of labor and management to provide better animal care. Future software upgrades may incorporate artificial intelligence that will interpret data and recommend possible actions and solutions.

\section{Technologies of Emerging Application}

During the last $25 \mathrm{yr}$, much has been learned about the molecular make-up of living organisms. The term "genomics" refers to the study of nucleic acids (e.g., DNA and RNA) within cells. In 2003, the USDA, in collaboration with the National Institutes of Health, announced the Bovine Genome Sequencing Project (Moore and Thatcher, 2006). The entire bovine genome has now been sequenced to reveal approximately 3 billion nucleotides with approximately $1 \%$ coding for functional genes, of which $40 \%$ or more of the genes have unknown functions. This technology is now being 
applied in addition to traditional progeny testing to rank potential young sires that express desirable genes coding for important economic traits for breeding and future selection purposes. With release of genomic evaluations in 2009, information about a cow's or bull's genetic potential that previously would have taken years to obtain by progeny testing was revealed at a young age, reducing the generation interval from 5 to $2 \mathrm{yr}$, and thus increasing the rate of genetic progress.

With greater rates of genetic progress, it is important that proper emphasis of reproductive traits be considered. Part of the Holstein Total Performance Index includes a fertility index. The new fertility index combines several reproductive components into one overall index, including ability to conceive as a maiden heifer (heifer conception rate and daughter pregnancy rate), ability to conceive as a lactating cow (cow conception rate), and a cow's overall ability to reinitiate postpartum estrous cycles, express estrus, conceive, and maintain a pregnancy. Emphasis on these traits, including longevity, which itself is heavily dependent on reproductive efficiency of the cow, must continue. Therefore, future prospects are real for improving reproductive performance of dairy cows through genetic selection based on early genomic tests.

Although milk yield is often implicated as the cause of impaired fertility (Bello et al., 2012), the effect of inadequate body condition may be greater (Carvalho et al., 2014; Zachut and Moallem, 2017) because it has significant effects on the probability of conception, rate of embryo loss, and proportion of anestrous cows (Weigel, 2006). Selection for or against certain traits could lead to improved fertility of dairy cattle. For example, because of the high energy demand for rapidly increasing milk production and limited feed intake in the transition period around parturition, dairy cows require considerable metabolic adaptations. Some cows may be genetically less suited to cope with these metabolic needs than others, leading to adverse follow-up effects on longevity. In a recent study (Ha et al., 2017), functional lifetime of dairy cows was linked to the metabolic challenges in the beginning of the first lactation (e.g., sum of milk yield or the accumulated fat-to-protein ratio of the first 3 test-days ( $<120$ DIM). Significant sire variance indicated a genetic component for metabolic adaptability and suggested that the ability to cope with metabolic stress in the transition period has a genetic component, which may be used to select metabolically more robust dairy cows.

\section{REFERENCES}

Allen, E., and E. A. Doisy. 1923. An ovarian hormone preliminary report on its location, extraction and partial purification, and action in test animals. J. Am. Med. Assoc. 81:819-821.
Allen, W. M. 1930. Physiology of the corpus luteum, V: The preparation and some chemical properties of progestin, a hormone of the corpus luteum which produces progestational proliferation. Am. J. Physiol. 92:174-188.

Amoss, M., R. Burgus, R. Blackwell, W. Vale, R. Fellows, and R. Guillemin. 1971. Purification, amino acid composition and N-terminus of the hypothalamic luteinizing hormone releasing factor (LRF) ovine origin. Biochem. Biophys. Res. Commun. 44:205-210.

Anon. 1975. Colloque: Control of sexual cycles in domestic animals. Accessed February 19, 2017. http://rnd.edpsciences.org/articles/ rnd/abs/1975/02/contents/contents.html.

Bauman, D. E. 1992. Bovine somatotropin: Review of an emerging animal technology. J. Dairy Sci. 75:3432-3451.

Bearden, W. H., and J. W. Fuquay. 1997. Applied Animal Reproduction. Prentice Hall College Division, Mishawaka, IN.

Bello, N. M., J. S. Stevenson, and R. J. Tempelman. 2012. Milk production and reproductive performance: Modern interdisciplinary insights into an enduring axiom. J. Dairy Sci. 95:5461-5475.

Bisinotto, R. S., E. S. Ribeiro, L. T. Martins, R. S. Marsola, L. F. Greco, M. G. Favoreto, C. A. Risco, W. W. Thatcher, and J. E. Santos. 2010. Effect of interval between induction of ovulation and artificial insemination (AI) and supplemental progesterone for resynchronization on fertility of dairy cows subjected to a 5-d timed AI program. J. Dairy Sci. 93:5798-5808.

Bisinotto, R. S., I. J. Lean, W. W. Thatcher, and J. E. Santos. 2015. Meta-analysis of progesterone supplementation during timed artificial insemination programs in dairy cows. J. Dairy Sci. 98:24722487.

Bisinotto, R. S., E. S. Ribeiro, and J. E. P. Santos. 2014. Synchronisation of ovulation for management of reproduction in dairy cows. Animal 8:151-159.

Borchardt, S., P. Haimer, and W. Heuwieser. 2016. Effect of insemination after estrous detection on pregnancy per artificial insemination and pregnancy loss in a Presynch-Ovsynch protocol: A metaanalysis. J. Dairy Sci. 99:2248-2256.

Borchardt, S., P. Haimer, A. Pohl, and W. Heuwieser. 2017. Evaluation of prostaglandin $\mathrm{F}_{2 \alpha}$ versus prostaglandin $\mathrm{F}_{2 \alpha}$ plus gonadotropinreleasing hormone as Presynch methods preceding an Ovsynch in lactating dairy cows: A meta-analysis. J. Dairy Sci. 100:4065-4077. https://doi.org/10.3168/jds.2016-11956.

Boyd, L. J. 1970. Effects of feeding melengestrol acetate (MGA) on occurrence of estrus, fertility and milk yield in dairy cows. J. Anim. Sci. 31:751-754.

Bratton, R. W., R. H. Foote, and J. C. Cruthers. 1955. Preliminary fertility results with frozen bovine spermatozoa. J. Dairy Sci. $38: 40-46$

Brewster, J. E., and C. L. Cole. 1941. The time of ovulation in cattle. J. Dairy Sci. 21:111-115

Britt, J. H., N. M. Cox, and J. S. Stevenson. 1981. Advances in reproduction in dairy cattle. J. Dairy Sci. 64:1378-1402.

Britt, J. H., E. Huertasvega, and L. C. Ulberg. 1972. Managing reproduction in dairy cattle. I. Progestogens for control of estrus in dairy cows. J. Dairy Sci. 55:598-605.

Britt, J. H., R. J. Kittok, and D. S. Harrison. 1974. Ovulation, estrus and endocrine response after GnRH in early postpartum cows. J. Anim. Sci. 39:915-919.

Britt, J. H., R. G. Scott, J. D. Armstrong, and M. D. Whitacre. 1986. Determinants of estrous behavior in lactating Holstein cows. J. Dairy Sci. 69:2195-2202.

Bruno, R. G. S., A. M. Farias, J. A. Hernandez-Rivera, A. E. Navarrette, D. E. Hawkins, and T. R. Bilby. 2013. Effect of gonadotropin-releasing hormone or prostaglandin $\mathrm{F}_{2 \alpha}$-based estrus synchronization programs for first or subsequent artificial insemination in lactating dairy cows. J. Dairy Sci. 96:1556-1567.

Bruno, R. G. S., J. G. N. Moraes, J. A. H. Hernandez-Rivera, K. J. Lager, P. R. B. Silva, A. L. A. Scanavez, L. G. D. Mendonca, R. C. Chebel, and T. R. Bilby. 2014. Effect of an Ovsynch56 protocol initiated at different intervals after insemination with or without a presynchronizing injection of gonadotropin-releasing hormone on fertility in lactating dairy cows. J. Dairy Sci. 97:185-194. 
Bruyère, P., T. Hétreau, C. Ponsart, J. Gatien, S. Buff, C. Disenhaus, O. Giroud, and P. Guérin. 2012. Can video cameras replace visual estrus detection in dairy cows? Theriogenology 77:525-530.

Cabrera, V. 2017. Value of Reproductive Improvement. Accessed 2013. http://www.dairymgt.info/tools.php.

Caraviello, D. Z., K. A. Weigel, P. M. Fricke, M. C. Wiltbank, M J. Florent, N. B. Cook, K. V. Nordlund, N. R. Zwald, and C. L. Rawson. 2006. Survey of management practices on reproductive performance of dairy cattle on large U. S. commercial farms. J. Dairy Sci. 89:4723-4735.

Carrick, M. J., and J. N. Shelton. 1967. The synchronization of oestrus in cattle with progestagen-impregnated intravaginal sponges. J. Reprod. Fertil. 14:21-32.

Carvalho, P. D., A. H. Souza, M. C. Amundson, K. S. Hackbart, M. J. Fuenzalida, M. M. Herlihy, H. Ayres, A. R. Dresch, L. M. Vieira, J. N. Guenther, R. R. Grummer, and P. M. Fricke. 2014 Relationships between fertility and postpartum changes in body condition and body weight in lactating dairy cows. J. Dairy Sci. 97:3666-3683

Casida, L. E. 1938. The preparation, properties and use of gonadstimulating hormones. J. Dairy Sci. 21:101-108.

Chebel, R. C., A. A. Scanavez, P. R. B. Silva, J. G. N. Moraes, L. G. D. Mendonca, and G. Lopes. 2013. Evaluation of presynchronized resynchronization protocols for lactating dairy cows. J. Dairy Sci. 96:1009-1020.

Davis, H. P., and B. Brost. 1953. Studies of herd management records I. Services required for conception for first to tenth calving. J. Dairy Sci. 36:1112-1116.

DeJarnette, J. M., R. L. Nebel, and C. E. Marshall. 2009. Evaluating the success of sex-sorted semen in US dairy herds from on farm records. Theriogenology 71:49-58.

Denis-Robichaud, J., R. L. A. Cerri, A. Jones-Bitton, and S. J. LeBlanc. 2016. Survey of reproduction management on Canadian dairy farms. J. Dairy Sci. 99:9339-9351.

Dewey, S. T., L. G. D. Mendonça, G. Lopes Jr., F. A. Rivera, F. Guagnini, R. C. Chebel, and T. R. Bilby. 2010. Resynchronization strategies to improve fertility in lactating dairy cows utilizing a presynchronization injection of $\mathrm{GnRH}$ or supplemental progesterone: I. Pregnancy rates and ovarian responses. J. Dairy Sci. 93:4086-4095

Dransfield, M. B., R. L. Nebel, R. E. Pearson, and L. D. Warnick. 1998. Timing of insemination for dairy cows identified in estrus by a radio telemetric estrus detection system. J. Dairy Sci. 81:18741882

El-Zarkouny, S. Z., J. A. Cartmill, B. A. Hensley, and J. S. Stevenson. 2004. Pregnancy in dairy cows after synchronized ovulation regimens with or without presynchronization and progesterone. J. Dairy Sci. 87:1024-1037.

Ferguson, J. D., and A. Skidmore. 2013. Reproductive performance in a select sample of dairy herds. J. Dairy Sci. 96:1269-1289.

Fevold, H. L., F. L. Hisaw, and S. L. Leonard. 1931. The gonad stimulating and the luteinizing hormones of the anterior lobe of the hypophysis. Am. J. Physiol. 97:291-301.

Firk, R., E. Stamer, W. Junge, and J. Krieter. 2002. Automation of oestrus detection in dairy cows: A review. Livest. Prod. Sci. 75:219-232.

Folman, Y., M. Kaim, Z. Herz, and M. Rosenberg. 1984. Reproductive management of dairy cattle based on synchronization of estrous cycles. J. Dairy Sci. 67:153-160.

Foote, R. H. 1975. Estrus detection and estrus detection aids. J. Dairy Sci. 58:248-256.

Foote, R. H. 1979. Time of artificial insemination and fertility in dairy cattle. J. Dairy Sci. 62:355-358.

Foote, R. H. 1996. Dairy cattle reproductive physiology research and management- past progress and future prospects. J. Dairy Sci. 79:980-990.

Foote, R. H. 2002. The history of artificial insemination: Selected notes and notables. J. Anim. Sci. 80(E-Suppl. 2):1-10.

Fricke, P. M. 2002. Scanning the future-Ultrasonography as a reproductive management tool for dairy cattle. J. Dairy Sci. 85:19181926 .
Fricke, P. M. 2004. Strategies for optimizing reproductive management of dairy heifers. Pages 163-176 in Proc. Western Canadian Dairy Seminar, Red Deer, Alberta, Canada. http://www.wcds.ca/proc/ 2004/Manuscripts/163Fricke.pdf.

Fricke, P. M., A. Ricci, J. O. Giordano, and P. D. Carvalho. 2016. Methods for and implementation of pregnancy diagnosis in dairy cows. Vet. Clin. North Am. Food Anim. Pract. 32:165-180.

Giordano, J. O., P. M. Fricke, J. N. Guenther, G. Lopes Jr., M. M. Herlihy, A. B. Nascimento, and M. C. Wiltbank. 2012a. Effect of progesterone on magnitude of the luteinizing hormone surge induced by 2 different doses of gonadotropin-releasing hormone in lactating dairy cows. J. Dairy Sci. 95:3781-3793.

Giordano, J. O., M. C. Wiltbank, P. M. Fricke, S. Bas, R. Pawlisch, J. N. Guenther, and A. B. Nascimento. 2013. Effect of increasing GnRH and $\mathrm{PGF}_{2 \alpha}$ dose during Double-Ovsynch on ovulatory response, luteal regression, and fertility of lactating dairy cows. Theriogenology 80:773-783.

Giordano, J. O., M. C. Wiltbank, J. N. Guenther, M. S. Ares, G. Lopes Jr., M. M. Herlihy, and P. M. Fricke. 2012b. Effect of presynchronization with human chorionic gonadotropin or gonadotropin-releasing hormone 7 days before resynchronization of ovulation on fertility in lactating dairy cows. J. Dairy Sci. 95:5612-5625.

Giordano, J. O., M. C. Wiltbank, J. N. Guenther, R. Pawlisch, S. Bas, A. P. Cunha, and P. M. Fricke. 2012c. Increased fertility in lactating dairy cows resynchronized with Double-Ovsynch compared with Ovsynch initiated $32 \mathrm{~d}$ after timed artificial insemination. J. Dairy Sci. 95:639-653.

Gomes, W. R., and R. E. Erb. 1965. Progesterone in bovine reproduction: A review. J. Dairy Sci. 48:314-330.

Ha, N.-T., A. R. Sharifi, J. Heise, M. Schlather, U. Schnyder, J. J. Gross, F. Schmitz-Hsu, R. M. Bruckmaier, and H. Simianer. 2017. A reaction norm sire model to study the effect of metabolic challenge in early lactation on the functional longevity of dairy cows. J. Dairy Sci. 100:3742-3753. https://doi.org/10.3168/jds.2016-12031.

Hansel, W. 1961. Estrous cycle and ovulation control in cattle. J. Dairy Sci. 44:2307-2314.

Hisaw, F. L., and R. K. Meyer. 1929. The oestrous producing hormone in the urine of pregnant cows. Proc. Soc. Exp. Biol. Med. $25: 586-588$

Johnson, A. D., R. M. Myers, and L. C. Ulberg. 1964. A method for evaluating the current reproductive status of a dairy herd. J. Am. Vet. Med. Assoc. 144:994-997.

Kiser, T. E., J. H. Britt, and H. D. Ritchie. 1977. Testosterone treatment of cows for use in detection of estrus. J. Anim. Sci. 44:1030 1035 .

Kittok, R. J., J. H. Britt, and E. M. Convey. 1973. Endocrine response after $\mathrm{GnRH}$ in luteal phase cows and cows with ovarian follicular cysts. J. Anim. Sci. 37:985-989.

Lauderdale, J. W. 2009. Contributions in the Journal of Animal Science to the development of protocols for breeding management of cattle through synchronization of estrus and ovulation. J. Anim. Sci. 87:801-812

Lewis, G. S., and S. K. Newman. 1984. Changes throughout estrous cycles of variables that might indicate estrus in dairy cows. J. Dairy Sci. 67:146-152.

Lima, F. S., H. Ayres, M. G. Favoreto, R. S. Bisinotto, L. F. Greco, E. S. Ribeiro, P. S. Baruselli, C. A. Risco, W. W. Thatcher, and J. E. Santos. 2011. Effects of gonadotropin-releasing hormone at initiation of the 5-d timed artificial insemination (AI) program and timing of induction of ovulation relative to $\mathrm{AI}$ on ovarian dynamics and fertility of dairy heifers. J. Dairy Sci. 94:4997-5004.

Louca, A., and J. E. Legates. 1968. Production losses in dairy cattle due to days open. J. Dairy Sci. 51:573-583.

Lucy, M. C., and J. S. Stevenson. 1986. Gonadotropin-releasing hormone at estrus: Luteinizing hormone, estradiol, and progesterone during the periestrual and post insemination periods in dairy cattle. Biol. Reprod. 35:300-311.

Macmillan, K. L., and A. J. Peterson. 1993. A new intravaginal progesterone releasing device for cattle (CIDR-B) for oestrous synchronisation, increasing pregnancy rates and the treatment of postpartum anoestrus. Anim. Reprod. Sci. 33:1-25. 
Matsuo, H., A. Arimura, R. M. G. Nair, and A. V. Schally. 1971a. Synthesis of the porcine LH- and FSH-releasing hormone by the solidphase method. Biochem. Biophys. Res. Commun. 45:822-827.

Matsuo, H., Y. Baba, R. M. G. Nair, A. Arimura, and A. V. Schally. 1971b. Structure of the porcine LH- and FSH-releasing hormone. I. The proposed amino acid sequence. Biochem. Biophys. Res. Commun. 43:1334-1339.

Mauer, R. E., S. K. Webel, and M. D. Brown. 1975. Ovulation control in cattle with progesterone intravaginal device (PRID) and gonadotropin releasing hormone $(\mathrm{GnRH})$. Ann. Biol. Anim. Biochim. Biophys. 15:291-296.

Mead, S. W. 1938. A diagrammatic method of presenting the history of reproduction in a dairy herd. J. Dairy Sci. 21:283-287.

Midgley, A. R. Jr., G. D. Niswender, and R. W. Rebar. 1969. Principles for the assessment of the reliability of radioimmunoassay methods (Precision, Accuracy, Sensitivity, Specificity). Acta Endocrinol. Suppl. (Copenh.) 142:163-184.

Moore, K., and W. W. Thatcher. 2006. Major advances associated with reproduction in dairy cattle. J. Dairy Sci. 89:1254-1266.

Moreira, F., C. Orlandi, C. A. Risco, R. Mattos, F. Lopes, and W. W. Thatcher. 2001. Effects of presynchronization and bovine somatotropin on pregnancy rates to a timed artificial insemination protocol in lactating dairy cows. J. Dairy Sci. 84:1646-1659.

NAHMS (National Animal Health Monitoring Service). 2007. Reproductive practices on U.S. dairy operations, 2007. Accessed February 24, 2017. https://www.aphis.usda.gov/animal_health/nahms/ dairy/downloads/dairy07/Dairy07_is_ReprodPrac.pdf.

NAHMS (National Animal Health Monitoring Service). 2014. Dairy cattle management practices in the United States, 2014. Accessed February 24, 2017. https://www.aphis.usda.gov/aphis/ourfocus/ animalhealth/monitoring-and-surveillance/nahms/nahms_dairy _studies.

Nalbandov, A., and L. E. Casida. 1940. Gonadotropic action of pituitaries from pregnant cows. Endocrinology 27:559-566.

Navanukraw, C., D. A. Redmer, L. P. Reynolds, J. D. Kirsch, A. T. Grazul-Bilska, and P. M. Fricke. 2004. A modified presynchronization protocol improves fertility to timed artificial insemination in lactating dairy cows. J. Dairy Sci. 87:1551-1557.

NDFS (Northeast Dairy Farm Study). 2015. Farm Credit East. C. Laughton, ed. Accessed March 10, 2017. http://www.dairychallenge .org/pdfs/2016_Northeast/2015_DFS_Final.pdf.

Nebel, R. L. 2015. Activity monitoring systems: What's new and what's improved? Pages 28-34 in Proc. 2015 Annu. Mtg. Dairy Cattle Reprod. Counc., Buffalo, NY. Dairy Cattle Reprod. Counc., New Prague, MN.

Nebel, R. L., W. L. Walker, M. L. McGilliard, C. H. Allen, and G. S. Heckman. 1994. Timing of artificial insemination of dairy cows: Fixed time once daily versus morning and afternoon. J. Dairy Sci. $77: 3185-3191$

Nellor, J. E., and H. H. Cole. 1956. The hormonal control of estrus and ovulation in the beef heifer. J. Anim. Sci. 15:650-661.

Neves, R. C., K. E. Leslie, J. S. Walton, and S. J. LeBlanc. 2012. Reproductive performance with an automated activity monitoring system versus a synchronized breeding program. J. Dairy Sci. 95:5683-5693.

Nibler, C. W., and C. W. Turner. 1929. The ovarian hormone content of pregnant cow's urine. J. Dairy Sci. 12:491-506.

Niswender, G. D., L. E. Reichert Jr., A. R. Midgley Jr., and A. V. Nalbandov. 1969. Radioimmunoassay for bovine and ovine luteinizing hormone. Endocrinology 84:1166-1173.

NMPF (National Milk Producers Federation). 2016. Dairy Producer Highlights (self-published). NMPF, Arlington, VA.

Østergaard, S., N. C. Friggens, and M. G. Chagunda. 2005. Technical and economic effects of an inline progesterone indicator in a dairy herd estimated by stochastic simulation. Theriogenology 64:819-843.

Patterson, D. J., G. H. Kiracofe, J. S. Stevenson, and L. R. Corah. 1989. Control of the bovine estrous cycle with melengestrol acetate (MGA). J. Anim. Sci. 67:1895-1906.
Perry, E. J., J. W. Bartlett, G. E. Taylor, J. Edwards, C. E. Terrill, V. Berliner, and F. P. Jeffrey. 1945. The Artificial Insemination of Farm Animals. Rutgers University Press, New Brunswick, NJ.

Pharriss, B. B., and L. J. Wyngarden. 1969. The effect of prostaglandin $\mathrm{F}_{2 \alpha}$ on the progestin content of ovaries from pseudo pregnant rats. Proc. Soc. Exp. Biol. Med. 130:92-94.

Plunkett, S. S., J. S. Stevenson, and E. P. Call. 1984. Uses of prostaglandin $\mathrm{F}_{2 \alpha}$ in lactating dairy cows with a palpable corpus luteum but unobserved estrus. J. Dairy Sci. 67:380-387.

Pursley, J. R., M. R. Kosorok, and M. C. Wiltbank. 1997. Reproductive management of lactating dairy cows using synchronization of ovulation. J. Dairy Sci. 80:301-306.

Rabaglino, M. B., C. A. Risco, M. J. Thatcher, I. H. Kim, J. E. Santos, and W. W. Thatcher. 2010a. Application of one injection of prostaglandin $\mathrm{F}_{2 \alpha}$ in the five-day Co-Synch + CIDR protocol for estrous synchronization and resynchronization of dairy heifers. J. Dairy Sci. 93:1050-1058.

Rabaglino, M. B., C. A. Risco, M. J. Thatcher, F. Lima, J. E. Santos, and W. W. Thatcher. 2010b. Use of a five-day progesterone-based timed AI protocol to determine if flunixin meglumine improves pregnancy per timed AI in dairy heifers. Theriogenology 73:13111318.

Ragan, V. E. 2002. The Animal and Plant Health Inspection Service (APHIS) brucellosis eradication program in the United States. Vet. Microbiol. 90:11-18.

Ribeiro, E. S., R. G. Bruno, A. M. Farias, J. A. Hernández-Rivera, G. C. Gomes, R. Surjus, L. F. Becker, A. Birt, T. L. Ott, J. R. Branen, R. G. Sasser, D. H. Keisler, W. W. Thatcher, T. R. Bilby, and J. E. Santos. 2014. Low doses of bovine somatotropin enhance conceptus development and fertility in lactating dairy cows. Biol. Reprod. 90:10.

Ricci, A., P. D. Carvalho, M. C. Amundson, R. H. Fourdraine, L. Vincenti, and P. M. Fricke. 2015. Factors associated with pregnancyassociated glycoprotein (PAG) levels in plasma and milk of Holstein cows during early pregnancy and their effect on the accuracy of pregnancy diagnosis. J. Dairy Sci. 98:2502-2514.

Roche, J. F. 1975. Synchronization of oestrus in cows using intravaginal silastic coils containing progesterone. Ann. Biol. Anim. Biochim. Biophys. 15:301-302.

Rodriguez-Martinez, H. 2012. Assisted reproductive techniques fro cattle breeding in developing countries: A critical appraisal of their value and limitations. Reprod. Domest. Anim. 47(Suppl. 1):21-26.

Roelofs, J., F. Lopez-Gatius, R. H. F. Hunter, F. J. C. M. van Eerdenburg, and Ch. Hanzen. 2010. When is a cow in estrus? Clinical and practical aspects. Theriogenology 74:327-344.

Santos, J. E. P., C. D. Narciso, F. Rivera, W. W. Thatcher, and R. C. Chebel. 2010. Effect of reducing the period of follicle dominance in a timed artificial insemination protocol on reproduction of dairy cows. J. Dairy Sci. 93:2976-2988.

Santos, J. E. P., W. W. Thatcher, R. C. Chebel, R. L. A. Cerri, and K. N. Galvão. 2004. The effect of embryonic death rates in cattle on the efficacy of estrus synchronization programs. Anim. Reprod. Sci. 82-83:513-535.

Santos, V. G., P. D. Carvalho, C. Maia, B. Carneiro, A. Valenza, P. M. Crump, and P. M. Fricke. 2016. Adding a second prostaglandin F $2 \alpha$ treatment to but not reducing the duration of a PRID-Synch protocol increases fertility after resynchronization of ovulation in lactating Holstein cows. J. Dairy Sci. 99:3869-3879.

Sauls, J. A., E. Voelz, S. L. Hill, L. G. D. Mendonça, and J. S. Stevenson. 2017. Increasing estrus expression in the lactating dairy cow. J. Dairy Sci. 100:807-820.

Seidel, G. E. Jr. 2014. Update on sexed semen technology in cattle. Animal 8(Suppl. 1):160-164.

Silva, E., R. A. Sterry, D. Kolb, M. C. Wiltbank, and P. M. Fricke. 2007. Effect of pretreatment with prostaglandin F2alpha before resynchronization of ovulation on fertility of lactating dairy cows. J. Dairy Sci. 90:5509-5517.

Souza, A. H., H. Ayres, R. M. Ferreira, and M. C. Wiltbank. 2008. A new presynchronization system (Double-Ovsynch) increases fertility at first postpartum timed AI in lactating dairy cows. Theriogenology 70:208-215. 
Spielman, A., and J. R. Jones. 1939. The reproductive efficiency of dairy cattle. J. Dairy Sci. 22:329-334.

Stevenson, J. S. 2016. Synchronization and artificial insemination strategies in dairy herds. Vet. Clin. North Am. Food Anim. Pract. 32:349-364.

Stevenson, J. S., J. J. Higgins, and Y. Jung. 2009. Pregnancy outcome after insemination of frozen-thawed bovine semen packaged in two straw sizes: A meta-analysis. J. Dairy Sci. 92:4432-4438.

Stevenson, J. S., S. L. Hill, R. L. Nebel, and J. M. DeJarnette. 2014 Ovulation timing and conception risk after automated activity monitoring in lactating dairy cows. J. Dairy Sci. 97:4296-4308.

Stevenson, J. S., and A. P. Phatak. 1999. Effective use of heat detection devices. Large Anim. Pract. 20:28-31.

Stevenson, J. S., and S. L. Pulley. 2012. Pregnancy per artificial insemination after presynchronizing estrous cycles with the Presynch-10 protocol or prostaglandin $\mathrm{F}_{2 \alpha}$ injection followed by gonadotropinreleasing hormone before Ovsynch-56 in 4 dairy herds of lactating dairy cows. J. Dairy Sci. 95:6513-6522.

Stevenson, J. S., M. W. Smith, J. R. Jaeger, L. R. Corah, and D. G. LeFever. 1996. Detection of estrus by visual observation and radiotelemetry in peripubertal, estrus-synchronized beef heifers. J. Anim. Sci. 74:729-735

Thatcher, W. W. 2017. A 100-Year Review: Historical development of female reproductive physiology in dairy cattle. J. Dairy Sci. 100:10272-10291.

Trimberger, G. W., and H. P. Davis. 1943. Conception rate in dairy cattle from artificial insemination at various stages of estrus. Nebraska Agric. Exp. Sta. Res. Bull. 129:1-14.

Trimberger, G. W., and W. Hansel. 1955. Conception rate and ovarian function following estrus control by progesterone injections in dairy cattle. J. Anim. Sci. 14:224-232.

Twagiramungu, H., L. A. Guilbault, and J. J. DuFour. 1995. Synchronization of ovarian follicular waves with a gonadotropin- releasing hormone agonist to increase the precision of estrus in cattle: A review. J. Anim. Sci. 73:3141-3151.

Ulberg, L. C., R. E. Christian, and L. E. Casida. 1951. Ovarian response in heifers to progesterone injections. J. Anim. Sci. 10:752759 .
USDA (United States Department of Agriculture). 2017. Milk production. Accessed March 2, 2017. http://usda.mannlib.cornell.edu/ usda/current/MilkProd/MilkProd-02-21-2017.pdf.

Valenza, A., J. O. Giordano, G. Lopes Jr., L. Vincenti, M. C. Amundson, and P. M. Fricke. 2012. Assessment of an accelerometer system for detection of estrus and treatment with gonadotropin-releasing hormone at the time of insemination in lactating dairy cows. J. Dairy Sci. 95:7115-7127.

Vasconcelos, J. L. M., R. W. Silcox, G. J. M. Rosa, and M. C. Wiltbank. 1999. Synchronization rate, size of the ovulatory follicle, and pregnancy rate after synchronization of ovulation beginning on different days of the cycle in lactating dairy cows. Theriogenology 52:1067-1078.

Weigel, K. A. 2006. Prospects for improving reproductive performance through genetic selection. Anim. Reprod. Sci. 96:323-330.

Willett, E. L. 1956. Developments in the physiology of reproduction of dairy cattle and in artificial insemination. J. Dairy Sci. 39:695-711.

Williams, W. L. 1919. A standard for measuring the reproductive and dairying efficiency of dairy cattle. Cornell Vet. 9:204-213.

Wiltbank, M. C. G. M. Baez, F. Cochrane, R. V. Barletta, C. R Trayford, and R. T. Joseph. 2015. Effect of a second treatment with prostaglandin $\mathrm{F}_{2 \alpha}$ during the Ovsynch protocol on luteolysis and pregnancy in dairy cows. J. Dairy Sci. 98:8644-8654.

Wiltbank, M. C., and J. R. Pursley. 2014. The cow as an induced ovulator: Timed AI after synchronization of ovulation. Theriogenology $81: 170-185$

Yalow, R. S. 1978. Radioimmunoassay: A probe for the fine structure of biologic systems. Science 200:1236-1245.

Zachut, M., and U. Moallem. 2017. Consistent magnitude of postpartum body weight loss within cows across lactations and the relation to reproductive performance. J. Dairy Sci. 100:3143-3154.

Zolman, J., E. M. Convey, J. H. Britt, and H. D. Hafs. 1973. Release of bovine luteinizing hormone by purified porcine and synthetic gonadotropin releasing hormone. Proc. Soc. Exp. Biol. Med. 142:189-193.

\section{APPENDIX}

Table A1. Timeline chronology of significant events and technologies developed to assist in reproductive management of dairy cattle; dates approximate development, introduction, patent issue, first use, or publication

\begin{tabular}{|l|l|l|}
\hline Date & Milestone & Reference \\
\hline 1905 & The Dairy Herd Improvement Association (DHIA) is organized. & \\
\hline 1914 & First artificial vagina is developed. & \\
\hline 1918 & Desirable age at first calving is described. & \\
\hline 1930 & Gonadotropin extracts are first described. & Casida, 1938 \\
\hline 1933 & Progesterone is isolated and characterized. & Gomes and Erb, 1965 \\
\hline 1937 & Rectovaginal cervical fixation method of Al is developed. & Perry et al., 1945 \\
\hline 1941 & Time of ovulation is determined. & Brewster and Cole, \\
\hline 1941 & Semen diluents for Al are introduced. & \\
\hline
\end{tabular}


Table A1 (Continued). Timeline chronology of significant events and technologies developed to assist in reproductive management of dairy cattle; dates approximate development, introduction, patent issue, first use, or publication

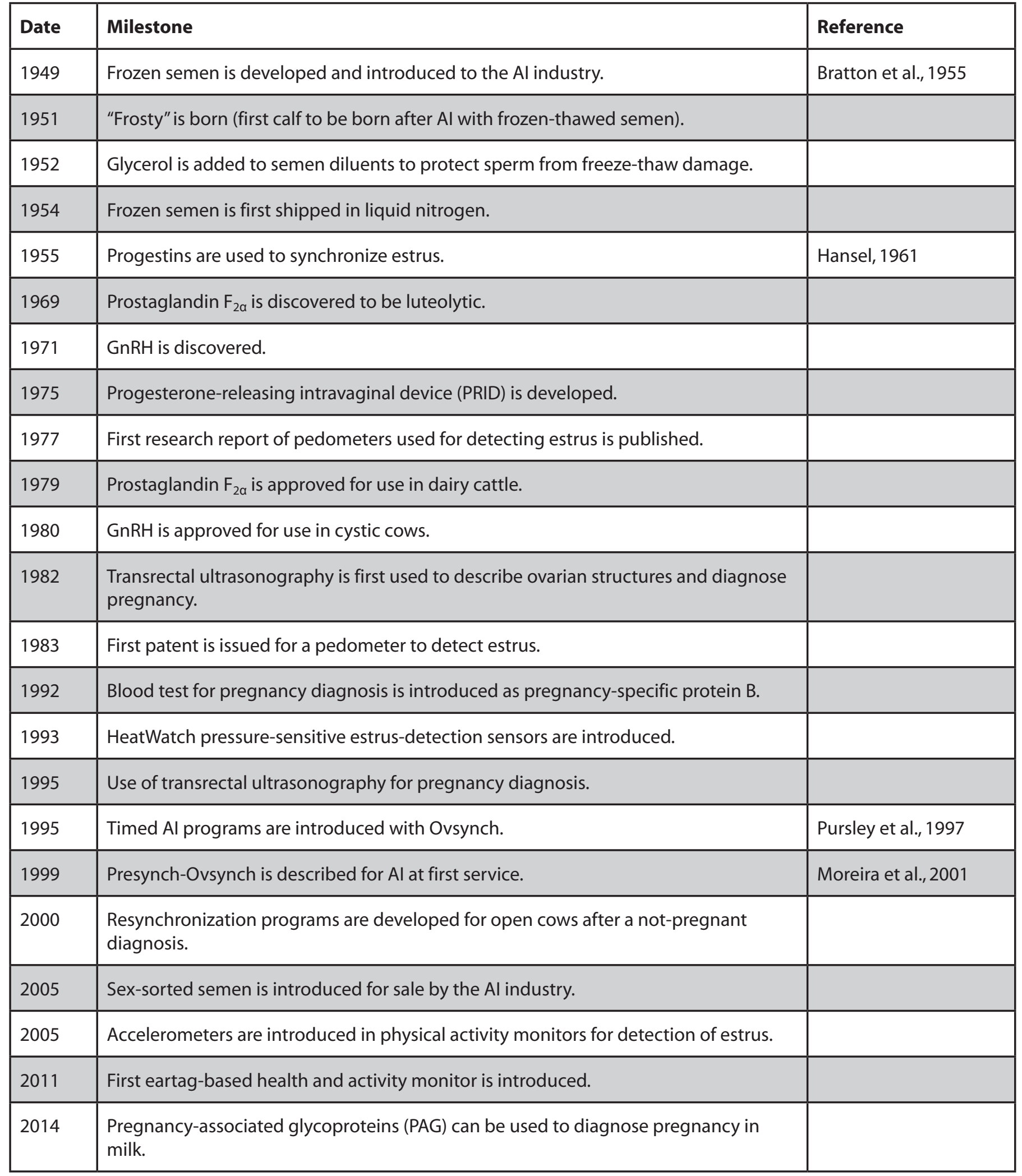

